\title{
Responsabilidad del Estado juez por extravío de expedientes judiciales sobre atentados terroristas -pérdida de oportunidad, prescripción y pervivencia de acciones civiles-
}

\author{
Blanca Soro Mateo \\ Profesora Titular de Derecho Administrativo \\ Universidad de Murcia
}

SUMARIO: I. LA RESPONSABILIDAD POR FUNCIONAMIENTO ANORMAL DE LA ADMINISTRAGIÓN DE JUSTICIA. 1. Marco jurídico general y presupuestos; 2. La pérdida de expediente como un claro supuesto de mal funcionamiento de la Administración de Justicia. II. LA JUSTIFICAGIÓN DEL DAÑO: PÉRDIDA DE EXPEDIENTE VS. PÉRDIDA DE OPORTUNIDAD O LUGRO CESANTE Y VULNERAGIÓN DE LA TUTELA JUdiGial EFEGTIVA. 1. Pérdida de oportunidad vs. lucro cesante en supuestos de pérdida de expediente judicial; A. La doctrina de la pérdida de oportunidad y su aplicación a los daños derivados del extravío del expediente judicial; B. El lucro cesante derivado de la frustración de la acción en casos de extravío de expedientes judiciales; C. Los daños indemnizables por pérdida de expediente judicial. 2. Vulneración de la tutela judicial efectiva por extravío de expediente judicial. III. PRESGRIPCIÓN DE LA ACGIÓN DE RESPONSABILIDAD POR PÉRDIDA DE EXPEDIENTE JUDICIAL. SOBRE LA DETERMINAGIÓN DEL DIE A QUO; LA EVENTUAL PERVIVENCIA DE LAS ACGIONES CIVILES DERIVADAS DEL ATENTADO EN SUPUESTOS DE EXTRAVÍO DEL EXPEDIENTE JUDICIAL. 1. Pervivencia de la acción en casos de sobreseimiento provisional no notificado al ofendido. 2. Pervivencia de acciones en el caso de que se pudiera probar la aplicación de la amnistía al responsable del atentado. 3. Prescripción de los atentados terroristas y de la responsabilidad civil derivada del delito.

RESUMEN: El presente estudio analiza el sistema de responsabilidad aplicable a los daños derivados del extravío de expedientes judiciales, especialmente de aquellos que traen causa de atentados terroristas. Se plantea el estudio de la natu- 
raleza del daño, de la prescripción de la acción de responsabilidad patrimonial y la prescripción de la acción civil derivada del atentado.

PALABRAS CLAVE: responsabilidad del poder judicial, extravío de expediente judicial atentado terrorista, prescripción

ABSTRACT: The study analyzes the system of liability applicable to the damages derived from the loss of judicial records, especially about terrorist attacks. It is based on the nature of the damage and the prescription of the liability action derived from the attack.

KEYWORDS: responsibility of the judiciary, loss of judicial file terrorist attack, prescription

\section{LA RESPONSABILIDAD POR FUNCIONAMIENTO ANORMAL DE LA ADMINISTRACIÓN DE JUSTICIA}

\section{Marco jurídico general y presupuestos}

El presente estudio se centra en el análisis del régimen de responsabilidad aplicable al extravío de expedientes judiciales especialmente de aquellos que traen causa de atentados terroristas, como categoría de supuestos que quedan incardinados en el marco del funcionamiento anormal de la Administración de Justicia con ocasión del desarrollo del proceso o de las actuaciones administrativas que constituyen el soporte de la función jurisdiccional ${ }^{1}$.

El establecimiento de un sistema de responsabilidad patrimonial del Estado por daños o perjuicios derivados de actuaciones de la Administración de Justicia, o también denominada Responsabilidad del Estado Juez, ha sido producto de una lenta evolución legislativa. Como ya advirtiera TORNOS MÁS, la Administración de Justicia respondió primero de forma subsidiaria por las conductas ilícitas de sus agentes, para pasar después a responder de forma directa a partir de la consagración de la responsabilidad patrimonial del Estado por el funcionamiento de la Administración de Justicia. El art. 121 CE consagró la responsabilidad patrimonial del Estado por error judicial o derivada del mal funcionamiento de la Administración de Justicia, disponiendo que "Los daños causados por error judicial, así como los que sean consecuencia del

MANTECA VALDELANDE, V., "Reclamación de responsabilidad a las Administraciones Públicas (VIII) (Responsabilidad derivada de actuaciones judiciales)", Actualidad Administrativa, núm. 6, Sección Práctica Profesional, tomo 1, Editorial LA LEY, 16-1 de marzo de 2011, p. 806. 
funcionamiento anormal de la Administración de Fusticia, darán derecho a una indemnización a cargo del Estado, conforme a la Ley"'.

El desarrollo del citado precepto constitucional fue abordado por la Ley Orgánica 6/1985, de 1 de julio, del Poder Judicial (LOPJ), que dedicó a regular esta cuestión sus arts. 292 a 297, preceptos a los que se remitiría la ya derogada Ley 30/1992, de 26 de noviembre, de Régimen jurídico de las Administraciones Públicas y del Procedimiento Administrativo Común (LRJPAG) al disciplinar el sistema de responsabilidad patrimonial de las Administraciones Públicas ${ }^{3}$ y, a día de hoy, el vigente art. 32.7 de la Ley 40/2015, de 1 de octubre, de Régimen Jurídico del Sector público (LRJSP) que, en los mismos términos que el que fuera su precedente, ha establecido que "La responsabilidad patrimonial del Estado por el funcionamiento de la Administración de Fusticia se regirá por la Ley Orgánica 6/1985, de1 de julio, del Poder Fudicial”.

Los arts. 292 a 297 de la LOPJ se ocuparon de establecer un régimen propio y diferenciado de responsabilidad de la Administración de Justicia en tres concretos supuestos: error judicial, funcionamiento anormal de la Administración de Justicia y prisión preventiva indebida ${ }^{4}$. En primer término, el art. 292.1 LOPJ advierte que "Los daños causados en cualesquiera bienes o derechos por error judicial, asi como los que sean consecuencia del funcionamiento anormal de la Administración de fusticia, darán a todos los perjudicados el derecho a una indemnización a cargo del Estado, salvo en los casos de fuerza mayor, con arreglo a lo dispuesto en este Título". Como se desprende del precepto transcrito, se reconoce la legitimación para reclamar a los "perjudicados", mas a renglón seguido el apartado 2 del mismo precepto legal utiliza el término "interesado" para referirse también a la legitimación activa en este tipo de procesos. De la conjunción de ambas disposiciones, que manejan conceptos no exactamente coincidentes, puede entenderse que "perjudicado" es aquel que ha sufrido el daño y que, por tanto, lo reclama directamente e "interesado" es aquel que, no habiendo sufrido directamente el daño, sin embargo, puede proceder a la reclamación de los perjuicios derivados del mismo, precisión -ésta última- relevante cuando se trata, como se verá infra, de reconocer legitimación a los familiares de las víctimas del terrorismo.

TORNOS MÁS, J., "La responsabilidad patrimonial del estado por el funcionamiento de la administración de justicia. Algunos aspectos conflictivos, con especial referencia al procedimiento para hacerla efectiva", Revista Española de Derecho Constitucional, núm. 13, 1985, pp. 75 y 76.

3 En efecto, el art. 139.4 de la LRJPAC dispuso que La responsabilidad patrimonial del Estado por el funcionamiento de la Administración de Fusticia se regirá por la Ley Orgánica del Poder Fudicial.

4 Esta regulación ha sufrido una reforma por obra de la Ley Orgánica 7/2015, de 21 de julio, que modifica la LOPJ, que se concreta en la supresión de la regulación especial de la responsabilidad civil de los Jueces y Magistrados, con el fin de igualar la posición de éstos con la de los demás empleados públicos, adecuándose así a las Recomendaciones del Consejo de Europa en este sentido. 
Por lo que se refiere ahora a los presupuestos del sistema e igual que sucede en el ámbito de la responsabilidad patrimonial de las Administraciones Públicas, para que proceda la responsabilidad del Estado por mal funcionamiento de la Administración de Justicia se exige que el daño alegado sea efectivo, evaluable económicamente e individualizado con relación a una persona o grupo de personas (art. 292.2 LOPJ). También deberá existir una relación de causalidad directa, inmediata y exclusiva entre la actuación del órgano judicial y el daño reclamado, precisándose, asimismo, que la mera revocación o anulación de las resoluciones judiciales no presupone, por sí sola, derecho a indemnización (art. 292.3 LOPJ), en similares términos a lo dispuesto por el art. 106 de la vigente LPAC respecto de la revisión de actos administrativos.

En cuanto a la competencia para conocer de estas reclamaciones y al plazo para el ejercicio de la acción de resarcimiento, el art. 293.1 LOPJ establece que el interesado dirigirá su petición indemnizatoria directamente al Ministerio de fusticia, tramitándose la misma con arreglo a las normas reguladoras de la responsabilidad patrimonial del Estado. La reclamación se presentará en el plazo de un año a partir del día en que pudo ejercitarse la acción y se tramitará con arreglo a las normas reguladoras de la responsabilidad patrimonial del Estado, procediendo recurso contencioso-administrativo en caso de denegación (art. 293.2 LOPJ). El dies a quo, como se ha señalado, se sitúa en el momento en que puede ejercitarse la acción, es decir, cuando concurren ya todos los requisitos que la hacen viable, entre ellos los mencionados en el art. 292.2 LOPJ. El procedimiento administrativo a seguir a partir de la entrada en vigor de las Leyes 39/2015 y 40/2015, que derogan el Real Decreto 429/1993, regulador del procedimiento para la exigencia de responsabilidad patrimonial de las Administraciones Públicas, será el Procedimiento Administrativo Común con las especialidades procedimentales que fija la Ley $39 / 2015^{5}$.

La aplicación jurisprudencial de los preceptos referidos sistematiza muy bien los presupuestos de la responsabilidad patrimonial de la Administración de Justicia en casos de mal funcionamiento. Así, entre otras, la STS (Sala de lo Contencioso-administrativo), de 21 de enero de 1999, sostiene que la viabilidad de la acción en estos casos requiere la concurrencia de los siguientes presupuestos o elementos del sistema: "a) La existencia de un daño efectivo, individualizado y evaluable económicamente. b) Que se haya

Deben tenerse en cuenta los siguientes preceptos: arts. 32 a 34 de la Ley 40/2015, art. 65 de la Ley 39/2015, sobre especialidades en el inicio de oficio de los procedimientos de responsabilidad patrimonial, art. 67 de la Ley 39/2015, sobre solicitudes de iniciación en los procedimientos de responsabilidad patrimonial, art. 81 Ley 39/2015 sobre solicitud de informes y dictámenes en los procedimientos de responsabilidad patrimonial; art. 86. 5 de la Ley 39/2015, sobre terminación convencional en responsabilidad patrimonial, art. 91 de la Ley 39/2015, sobre la resolución en los procedimientos en materia de responsabilidad patrimonial, y art. 92 de la Ley 39/2015, sobre competencia para la resolución de procedimientos de responsabilidad patrimonial. 

terroristas-pérdida de oportunidad, prescripción y pervivencia de acciones civiles-

producido un funcionamiento anormal de la Administración de fusticia. c) La concurrencia de la oportuna relación de causalidad entre el funcionamiento de la Administración de fusticia y el daño causado, de tal manera que éste aparezca como una consecuencia de aquél y por lo tanto resulte imputable a la Administración. d) Que la acción se ejercite dentro del plazo de un año desde que la producción del hecho determinante del daño propició la posibilidad de su ejercicio".

Por emblemática, pues abunda en el alcance del funcionamiento anormal, también interesa traer a colación la STS (Sala de lo Contencioso-administrativo) de 6 de julio de 1999. Al igual que advirtió la STS de 11 de noviembre de 1993, "la anormalidad de ese funcionamiento no implica, desde luego, referencia alguna necesaria al elemento de ilicitud o culpabilidad en el desempeño de las funciones judiciales al tratarse de un tipo de responsabilidad objetiva". A lo que añade que "El concepto de anormalidad en el funcionamiento de la Administración constituye un concepto jurídico indeterminado que debe quedar integrado en función de la naturaleza de los actos emanados de la función y las circunstancias concretas concurrentes en el supuesto enjuiciado". Por último, también la STS, (Sala de lo Contencioso-administrativo) de 11 de mayo de 1993 , precisa los requisitos del daño indemnizable, que ha de ser real y efectivo, "y que no se traduzca en meras especulaciones o expectativas-, que incida sobre derechos e intereses legítimos evaluables económicamente y cuya concreción cuantitativa o las bases para su determinación puedan materializarse en ejecución de sentencia, de manera que permitan una cifra individualizada en relación con una persona, como consecuencia del daño producido por la actividad de la Administración en relación de causa a efecto, probando el perjudicado la concurrencia de los requisitos legales para que surja la obligación de indemnizar.

\section{La pérdida de expediente como un claro supuesto de mal funcionamiento de la Administración de Justicia}

Como ya ha sido advertido, el mal funcionamiento de la Administración de Justicia es un concepto jurídico indeterminado que debe quedar integrado en función de la naturaleza de los actos emanados, de la función y las circunstancias concretas concurrentes, bastando con la constatación de que el daño sea consecuencia del anormal funcionamiento de la Administración ${ }^{6}$. Mas a renglón seguido ha de precisarse que la anormalidad del funcionamiento de la Administración de Justicia no implica, a juicio del TS, ilicitud o culpabilidad en el desempeño de las funciones judiciales, pues se trata, lejos de lo que pudiera parecer, de un tipo responsabilidad objetiva ${ }^{7}$. En dicha lógica, el alcance concepto de anormalidad en el funcionamiento de la Administración como concepto jurídico indeterminado debe ser concretado casuísticamente por los Jueces y Tribunales.

\footnotetext{
Así lo declara la STS (Sala de lo Contencioso-administrativo) de 15 de febrero de 1998 y en el mismo sentido la SAN (Sala de lo Contencioso-administrativo) de 1 de marzo de 2012.

Por todas, STS (Sala de lo Contencioso-administrativo) de 11 de noviembre de 1993.
} 
Del análisis de la interpretación judicial de dicho concepto puede concluirse que se aprecia funcionamiento anormal de la Administración de Justicia cuando las actuaciones procesales tengan una duración superior a la normal, dentro de lo que es una diligente tramitación del proceso (SsTS de 12 de junio de 1996, de 4 de enero y de 10 y 30 de mayo de 1990). De este modo, sin apreciar culpabilidad ni falta de diligencia imputable a los agentes de la Administración cabe un mal funcionamiento por retrasos injustificados o dilaciones indebidas, aunque según el TS, para estimar la existencia de dilación indebida no será suficiente el simple incumplimiento de plazos, que constituye a priori una irregularidad procesal, apelando al criterio de la razonabilidad para determinar los niveles de exigencia que la Administración de Justicia debe cumplir.

En relación con lo anterior, resulta ilustrativa la STS de 28 de junio de 1999, (Sala de lo Contencioso-administrativo) que advirtió en el sentido apuntado que “.... la existencia o no de retraso constitutivo de anormalidad en el funcionamiento de la Administración de Fusticia ha de valorarse, en aplicación del criterio objetivo que preside el instituto de la responsabilidad del Estado por el funcionamiento de los servicios públicos, partiendo de una apreciación razonable de los niveles de exigencia que la Administración de Fusticia, desde el punto de vista de la eficacia, debe cumplir según las necesidades de la sociedad actual y para alcanzar los cuales los poderes públicos están obligados a procurar los medios necesarios. Por eso, el simple incumplimiento de los plazos procesales meramente aceleratorios constituye una irregularidad procesal que no comporta, por sí misma, una anormalidad funcional que genere responsabilidad. Si constituye anormalidad, en cambio, una tardanza, tomando en cuenta la duración del proceso en sus distintas fases, que sea reconocida por la conciencia jurídica y social como impropia de un Estado que propugna como uno de sus valores superiores la justicia y reconoce el derecho a una tutela judicial eficaz'.

Para seguir avanzando en nuestro discurso, debe señalarse ahora que los supuestos incardinables en el funcionamiento anormal de la Administración de Justicia no pueden, sin embargo, quedar reducidos a las referidas dilaciones indebidas, sino que deben ser comprendidas también otras situaciones procesales de las que derivan daños imputables a la Administración de Justicia que los particulares no tienen el deber jurídico de soportar. La STS (Sala de lo Contencioso-administrativo) de 21 de diciembre de 1999 es ilustrativa de ello al ofrecer una visión más amplia del concepto de "funcionamiento anormal" de la Administración de Justicia. A juicio del TS " $n o$ puede quedar reducido exclusivamente a lo que en la sentencia recurrida se denomina "estructura ju-

$8 \quad$ No bastando, pues, limitarse a realizar en el escrito de reclamación o de demanda la solicitud de una indemnización por funcionamiento anormal, a partir de una narración de sucesivas actuaciones judiciales que se habian producido en el desarrollo del proceso penal de referencia, pero sin entrar en el detalle de aquellos lapsos de inactividad o paralización que hayan podido determinar una dilación indebida, o de aquellas otras actuaciones deficientes que eventualmente hayan coadyuvado al mismo resultado, limitándose la parte a enumerar determinados actos procesales propios del tracto sucesivo del procedimiento penal. Vid. en este sentido, la STS (Sala de lo Contencioso-administrativo) de 16 de junio de 2014. 

terroristas-pérdida de oportunidad, prescripción y pervivencia de acciones civiles-

dicial como servicio público", por más que las dilaciones indebidas constituyan el supuesto típico de funcionamiento anormal (...), sino que comprende también la omisión de fases o etapas procesales, trámites o requisitos, que impidan el recto enjuiciamiento de los asuntos".

Pues bien, entre estas situaciones procesales a las que se refiere el TS, no cabe duda que se encuentra también el supuesto de pérdida o extravío de expedientes judiciales. Se trata de un claro y evidente supuesto de anormal funcionamiento de la Administración de Justicia ${ }^{9}$, más grave aún que los enunciados supra, al impedir -no sólo dificultar o retrasar- al interesado la posibilidad de obtener una tutela judicial efectiva -en puridad, imposibilita obtener una resolución judicial sobre el fondo-, vulneración que debe ir acompañada del reconocimiento al perjudicado/interesado del derecho a percibir una indemnización por el perjuicio que para éste supone la pérdida del expediente judicial y que, como se verá, puede llegar a suponer la vulneración de un derecho fundamental.

El Consejo de Estado ha considerado reiteradamente que la pérdida del expediente judicial constituye, sin lugar a dudas, un supuesto incardinable en el funcionamiento anormal de la Administración de Justicia, en cuanto implica un deficiente cumplimiento de las obligaciones impuestas legalmente a los Secretarios Judiciales ${ }^{10}$. Así, el Dictamen del Consejo de Estado, núm. 2763/2002, de 31 de octubre de 2002, admite que se ha producido un funcionamiento anormal de la Administración de Justicia en estos casos, invocando el art. 473.3 de la LOPJ y el art. 6 del Reglamento Orgánico del Cuerpo de Secretarios, afirmando que forman parte de las obligaciones y responsabilidades de los Secretarios fudiciales, entre otras, asumir la guarda y depósito de la documentación, su archivo y la conservación de los bienes y objetos afectados a los expedientes judiciales; y encargarse de la llevanza de los libros y del archivo y de la conservación de las actuaciones. Por todo, la pérdida de un expediente judicial -como ha ocurrido en el presente caso- ha de considerarse un supuesto de funcionamiento anormal de la Administración de Fusticia. Aun cuando la pérdida se hubiera producido por el Servicio de Correos u otro de la Administración, circunstancia que no consta de la documentación que conforma el expediente, ello no exime a los Tribunales Superiores de Justicia implicados de realizar las averiguaciones pertinentes acerca del estado del expediente a tenor del art. 140 de la Ley 30/1992, ni excluiría en el presente supuesto el anormal funcionamiento de la Administración de Justicia, pues dicho precepto establece la responsabilidad solidaria de las Administraciones intervinientes "cuando de la gestión dimanante de fórmulas conjuntas de actuación

9 En parecidos términos se expresa la STS (Sala de lo Contencioso-administrativo) de 5 de febrero de 1992 y la STS de 19 de enero de 2015.

10 Vid. art. 473.3 de la LOPJ y art. 6.b) y g) del Reglamento Orgánico del Cuerpo de Secretarios Judiciales, aprobado por el Real Decreto 429/1988, de 29 de abril. Vid. asimismo, los Dictámenes del Consejo de Estado 1350/2004, de 8 de julio y 3126/2001, de 31 de enero, entre otros. 
entre varias Administraciones Públicas, se deriven responsabilidades en los términos previstos en la citada Ley"'ll.

Sentado lo anterior, veamos a continuación cuál es el daño cuya existencia debe probar el perjudicado y/o interesado para que sea indemnizable la pérdida del expediente judicial de acuerdo con el sistema descrito supra y cuál ha sido la jurisprudencia al respecto.

\section{LA JUSTIFICACIÓN DEL DAÑO: PÉRDIDA DE EXPEDIENTE VS. PÉRDIDA DE OPORTUNIDAD O LUGRO GESANTE Y VULNERACIÓN DE LA TUTELA JUDICIAL EFECTIVA}

Ya ha quedado advertido, al dar cuenta de los elementos del sistema de responsabilidad del Poder Judicial por mal funcionamiento de la Administración de Justicia que serán indemnizables los daños causados en cualesquiera bienes o derechos, salvo en los casos de fuerza mayor, que tengan su origen en los supuestos previstos en la LOPJ. En todo caso, el daño alegado ha de ser efectivo, evaluable económicamente e individualizado en relación a una persona o grupo de personas, condiciones idénticas a las que se exigen para apreciar un daño indemnizable conforme al sistema de responsabilidad patrimonial de las Administraciones Públicas. Asimismo, deberá existir una relación de causalidad directa, inmediata y exclusiva entre la actuación del órgano judicial, esto es, entre el mal funcionamiento y el daño reclamado.

Pero ¿cuál es el daño indemnizable en estos casos de pérdida del expediente judicial, la pérdida de oportunidad o el incierto lucro cesante?

\section{Pérdida de oportunidad vs. lucro cesante en supuestos de pérdida de expediente judicial}

A. La doctrina de la pérdida de oportunidad y su aplicación a los daños derivados del extravío del expediente judicial

En el ámbito de la responsabilidad, tanto en sede civil como administrativa, la "pérdida de oportunidad" es el daño que sufre quien ve comprometida una posibilidad real de obtener un beneficio o evitar un perjuicio ${ }^{12}$. La denominada doctrina de la pérdida de oportunidad ha venido siendo aplicada por nuestros Tribunales desde la década de los cincuenta a asuntos de responsabilidad civil profesional del abogado, ampliándose desde los ochenta al ámbito de la responsabilidad sanitaria. Dicha

11 Y en el mismo sentido y con idéntica fundamentación, los Dictámenes del Consejo de Estado núm. 1350/2004, de 8 de julio, y 2763/2002, de 31 de octubre de 2002.

12 MEDINA ALCOZ, L., La Teoría de la Pérdida de oportunidad. Estudio doctrinal y jurisprudencial de derecho de daños público y privado, Navarra, Editorial Aranzadi, 2007, p. 55. 
doctrina se gestó como respuesta a la necesidad de indemnizar los daños irrogados cuando la relación de causalidad no se podía demostrar; configurándose la posibilidad de obtener un beneficio o de evitar un perjuicio como un bien jurídico cuya desaparición provocaba un daño que como tal debía ser indemnizado ${ }^{13}$.

Este principio de origen jurisprudencial, también asumido por la doctrina del Consejo de Estado, no ha corrido la suerte de cristalizar, sin embargo, en las normas que regulan los diversos sistemas de responsabilidad en derecho español. Así, debe recurrirse a la jurisprudencia para conocer el alcance de esta doctrina y si resulta o no aplicable a los daños irrogados como consecuencia de la pérdida o extravío de expedientes judiciales.

Desde finales de los años ochenta, el orden jurisdiccional civil aplica la doctrina de la pérdida de oportunidad para resolver demandas frente a abogados y procuradores. De entre las negligencias profesionales indemnizables, según el TS, unas de las sin duda más frecuentes son aquellas en las que el abogado deja transcurrir el plazo de prescripción de la acción por responsabilidad civil extracontractual de su cliente, así como aquellas que dan lugar a que el acto administrativo devenga firme.

Asimismo, como se ha avanzado, son numerosos los pronunciamientos en los que se viene aplicando la pérdida de oportunidad en el ámbito sanitario. Así, y por lo que se refiere a la Jurisdicción contencioso-administrativa, se viene admitiendo la aplicación de esta doctrina para atemperar las rigurosas exigencias de la relación de causalidad cuando no puede asegurarse que la actuación culposa del profesional haya sido causante del daño objeto de reclamación, pero sí ha supuesto una pérdida de oportunidad de un diagnóstico o de un tratamiento más temprano. El cálculo de la indemnización en estos casos se efectúa atendiendo al porcentaje estadístico de probabilidades de curación si el interesado hubiera sido tratado correctamente. La doctrina de la "pérdida de oportunidad" deviene entonces aplicable en los supuestos de probabilidad causal incierta, pero no cuando no existe dicha probabilidad. En consecuencia, el primer problema que plantea la causalidad probabilística es determinar qué porcentaje de pérdida de oportunidad es necesario para admitir que concurre el requisito del nexo de casualidad exigible para que se aprecie responsabilidad.

13 Como ha puesto de manifiesto ASENSI PALLARÉS, el origen doctrinal de la pérdida de oportunidad se encuentra en los ordenamientos jurídicos francés (perte d'une chance) e inglés (loss of a chance of recovery), entre finales del siglo XIX y principios del siglo XX, introduciéndose después en EEUU, Canadá e Italia. Especialmente en Derecho norteamericano se ha forjado un sólido cuerpo doctrinal y jurisprudencial en torno a la a la perdida de oportunidad, que se aplica básicamente en supuestos de daños personales producidos en el ámbito sanitario. ASENSI PALLARÉS, E., "La evolución de la doctrina de la pérdida de oportunidad en responsabilidad médica", Revista Cesco de derecho de consumo, núm. 8/2013, p. 229, disponible en http://www.revista.uclm.es/index.php/cesco 
Nos referimos a continuación a los presupuestos que necesariamente han de concurrir para su aplicación, que han sido esgrimidos por la jurisprudencia en el ámbito de la responsabilidad sanitarial ${ }^{14}$ y de los profesionales jurídicos y que, por extensión, también deberían concurrir para poder apreciar la responsabilidad del Poder Judicial. En primer término, se exige una acción u omisión negligente y una incertidumbre causal entre la acción u omisión negligente y el daño final producido. Así, existiendo una oportunidad fundada, real y seria, frustrada ésta se impide la obtención del beneficio final, pero no se sabe si el resultado habría sido el mismo en otro caso ${ }^{15}$. En segundo lugar, esta figura supone configurar la pérdida de expectativas como un daño indemnizable autónomo. Lo que implica, como indica ARCOS VIEIRA, solucionar el problema de la relación de causalidad a costa de complicar el de la determinación y posterior valoración del daño ${ }^{16}$. En tercer término, debe repararse en que la pérdida de una oportunidad va a suponer el menoscabo de un bien distinto del que representa la ventaja final ${ }^{17}$.

La jurisprudencia se ha ocupado de analizar estos presupuestos. Así, y por lo que se refiere al alcance de la probabilidad, aunque en el ámbito de la responsabilidad sanitaria no encontramos criterios jurisprudenciales uniformes, en cambio, en relación a la responsabilidad civil de abogados y procuradores, el TS sí ha consolidado el criterio de la razonabilidad de la certidumbre de la probabilidad del resultado o la probabilidad de éxito de la acción frustrada para la determinación de la relevancia de la pérdida de oportunidad a efectos indemnizatorios. En efecto, cuando el abogado deja transcurrir el plazo de la acción de su cliente, el TS ha considerado que "el daño por pérdida de oportunidad no puede dar lugar a una indemnización cuando no hay una razonable certidumbre de la probabilidad del resultado"18. Mas otras veces ha reconocido que "la

14 ASÚA GONZÁLEZ, C.I., "Responsabilidad civil médica", en REGLERO CAMPOS, L.F. Y BUSTO LAGO, J.M (Coord.), Tratado de responsabilidad civil, Vol. II, 5ª Ed., Thomson Aranzadi, Cizur Menor, 2014, pp. 358-364.

15 En este sentido, vid., ASENSI PALLARÉS, E. (2013: p. 229) y ARCOS VIEIRA, M.L. "La 'pérdida de oportunidad' como daño indemnizable" en Estudos de direito do consumidor, Faculdade de Direito da Universidade de Coimbra, núm. 7, 2005, p. 169.

16 ARCOS VIEIRA, M.L. Responsabilidad civil: nexo causal e imputación objetiva en la jurisprudencia, Thomson Aranzadi, Cizur Menor, 2005, p. 55.

17 Así, en el ámbito sanitario, la STS (Sala de lo Civil) de 2 de enero de 2012 afirma que el retraso en el diagnóstico determinó que no se aplicara el tratamiento correcto, pero ello no supone sin más la indemnización de todo el daño acontecido, pues no se sabe si de haber sido diagnosticado con más rapidez el resultado se hubiera producido igualmente. Sin embargo, sí hubiera tenido más posibilidades de obtener un éxito, por lo que ha existido una privación de expectativas. En el mismo sentido, vid. SsTS (Sala de lo Contencioso-administrativo) de 27 de noviembre de 2012, de 23 de enero de 2012, de 19 de junio de 2012 y SsTS (Sala de lo Civil) de 22de abril de 2013 y de 28 de junio de 2012. Asimismo, STSJ de Madrid (Sala de lo Contencioso-administrativo) de 18 de diciembre de 2014 y STSJ de Castilla y León (Sala de lo Contencioso-administrativo) núm. 505/2015, de 13 de marzo de 2015.

18 Así, la STS de 24 de abril de 2015 (Sala de lo Civil) sobre responsabilidad por pérdida de oportunidad exige demostrar que el perjudicado se encontraba en una "situación fáctica o jurídica idónea 

terroristas-pérdida de oportunidad, prescripción y pervivencia de acciones civiles-

pretensión de resarcimiento de los recurrentes carecía de posibilidades de éxito, por lo que falta el requisito de la razonable certidumbre sobre la existencia de oportunidades de obtener buen éxito en el ejercicio de la acción, necesario para que pueda apreciarse la existencia de un daño resarcible ligado a la frustración de la acción ejercitada" "19. Se hace, pues, necesario valorar las probabilidades de éxito de la acción frustrada y si era viable, se entenderá que la conducta del abogado ha provocado la pérdida de unas probabilidades de éxito de la acción. Así lo ha entendido el TS en la STS (Sala de lo Civil) de 16 de diciembre de 1996, que entra a examinar las probabilidades de que la acción hubiera prosperado.

En el caso que nos ocupa, esto es, en relación con la pérdida de expedientes judiciales, sin embargo, puede entenderse que la relación de causalidad siempre será clara y cierta, pues es prácticamente seguro que la Administración de Justicia con su actuación ha causado el daño. También estará claro el daño objetivo que supone el impedir un pronunciamiento judicial sobre el fondo. Y, por último, se habrá frustrado una acción legítima que para el perjudicado supone la posibilidad de éxito del derecho a indemnización.

Lo difícil en estos casos será otorgar un valor económico a esa oportunidad perdida. Para la cuantificación del daño la STS (Sala de lo Contencioso-administrativo), de 4 de junio de 2003 consideró que el perjuicio, como consecuencia de la pérdida de oportunidad derivada de la pérdida del expediente judicial, consiste en privar al perjudicado de la tutela judicial efectiva, lo cual es que es subsumible en la noción de daño moral. Así, más que determinar cuál habría sido el resultado de la controversia objeto del proceso, es más indicado tener en cuenta el daño moral que se ha ocasionado por la pérdida de oportunidad, al no haber podido acceder a la tutela judicial efectiva. Por ello, para la determinación del alcance de la indemnización podría tomarse en consideración el equivalente al interés discutido en el proceso en el que se detecta el mal funcionamiento de la Administración de Justicia o bien ponderar dicho alcance en función de la probabilidad de éxito que habría tenido el proceso cuyo expediente se extravió, como sucede en los dos ámbitos vistos en los que se aplica la doctrina de la pérdida de oportunidad. Y es que, en el caso de extravío de expedientes judiciales, el alcance de la indemnización que debiera corresponder se encuentra muy próximo e incluso puede ser equivalente al interés patrimonial en

para realizarlas". De ello se desprende que es necesario que la acción que se iba a ejercitar contase con una razonable certidumbre de que podía prosperar. Esto significa que el perjudicado debía contar con una posibilidad seria y fundada de que su pretensión fuera estimada, pues en caso contrario se entiende que no se ha producido ningún perjuicio, ya que no había ninguna oportunidad y, por tanto, ninguna oportunidad se ha perdido

19 STS (Sala de lo Civil) núm. 967/2008, de 23 de octubre de 2008 y núm. 739/2013, de 19 de noviembre de 2013. Vid., SERRA RODRÍGUEZ, A. La responsabilidad civil del abogado, Aranzadi Editorial, $2^{\mathrm{a}}$ ed., Elcano, 2001, p. 245. 
juego en el proceso principal del que trae causa la pérdida de oportunidad por pérdida del expediente.

B. El lucro cesante derivado de la frustración de la acción en casos de extravío de expedientes judiciales

Aunque hasta aquí parece claro que el daño producido por la pérdida de un expediente judicial constituye un supuesto de pérdida de oportunidad, resulta conveniente que nos detengamos en la distinción entre pérdida de oportunidad y un concepto muy próximo, el lucro cesante, con el fin de descartar o no la posibilidad de que en los casos de extravío de expedientes judiciales nos encontremos ante un supuesto de lucro cesante.

Como es sabido, el lucro cesante es un daño patrimonial que se concreta en la ganancia que el perjudicado ha dejado de obtener o en la pérdida de ingresos sufrida como consecuencia directa e inmediata del hecho lesivo. La diferencia fundamental entre ambos conceptos - pérdida de oportunidad y lucro cesante- reside en que el lucro cesante implica la pérdida de unos ingresos que se esperaba obtener, mientras que la pérdida de oportunidad implica sólo la desaparición de la expectativa de ganancia, es decir, lo que se destruye es la probabilidad de que el perjudicado obtuviese una ganancia que era posible, pero no seguro, obtener. El lucro cesante es entonces un daño cierto en cuanto a la pérdida en sí de la probabilidad de ganancia, mientras que la pérdida de oportunidad plantea el problema de determinar la realidad y el alcance de las ganancias dejadas de obtener. En el primer caso, la relación de causalidad no ofrece dudas, mientras que en el segundo caso -pérdida de oportunidad-, puede afirmarse que esta es una ficción y que depende del grado de probabilidad de éxito de la acción.

A pesar de las diferencias apuntadas entre ambos conceptos, su proximidad ha llevado en alguna ocasión al TS a identificarlos, reconociendo indemnizaciones por pérdida de oportunidad por la totalidad del daño sufrido, como si se tratara de supuestos de lucro cesante. Así, la conocida STS (Sala de lo Civil) de 20 de mayo de 2014, que resuelve la reclamación de responsabilidad civil contra un abogado por actuación negligente en la defensa de los intereses de su cliente en orden a la obtención de las indemnizaciones que le hubieran podido corresponder por el fallecimiento de sus respectivos familiares en el siniestro del camping de Biescas en 1996, sostuvo que la acción inicial de reclamación por el siniestro habría prosperado con toda seguridad de haberse presentado a tiempo, ya que otros perjudicados que así lo hicieron obtuvieron sentencia estimatoria. De este modo, concedió a los demandantes la indemnización que les hubiera correspondido de haberse formulado a tiempo la reclamación.

A la luz de este pronunciamiento, aun habiéndose aplicado la doctrina de la pérdida de oportunidad, en la medida en que la negligencia del abogado no provocó una disminución de probabilidades de éxito de la acción frustrada, en puridad su 

terroristas-pérdida de oportunidad, prescripción y pervivencia de acciones civiles-

actuación impidió con certeza la llegada de unos ingresos al patrimonio de los perjudicados, lo cual supone la evidencia de un lucro cesante, por lo que puede afirmarse que los perfiles entre ambas instituciones continúan siendo difusos. Puede decirse, pues, que definir el daño como pérdida de oportunidad o como lucro cesante dependerá, en suma, del grado de certeza de obtener las cantidades indemnizatorias según el caso. Si las cantidades iban a llegar con certeza al patrimonio del interesado de no haber mediado la negligencia del abogado o, en nuestro caso, la pérdida del expediente judicial, nos encontraríamos ante un supuesto de lucro cesante, en cuyo caso deberá indemnizarse la totalidad del perjuicio producido y no únicamente la pérdida de unas expectativas de obtenerlo. En cambio, si se trata de una probabilidad, nos encontraríamos ante un supuesto de pérdida de oportunidad, que comprende sólo el daño moral y que no se identifica con la totalidad del daño producido que se corresponde con la cuantía del proceso principal.

\section{Los daños indemnizables por pérdida de expediente judicial}

La cuestión analizada supra, relativa a la dicotomía perdida de oportunidad vs. lucro cesante, enlaza inmediatamente con la relativa a la determinación del daño indemnizable. En efecto, debe determinarse entonces si son indemnizables los perjuicios derivados de la pérdida de oportunidad procesal o los daños derivados del objeto del proceso principal.

Ya ha podido comprobarse que no es en absoluto una tarea fácil determinar la dimensión del perjuicio derivado del mal funcionamiento de la Administración de Justicia ${ }^{20}$. En principio, nuestros Tribunales entienden que son indemnizables exclusivamente los daños morales que son consecuencia de la frustración del interés legítimo de la víctima en obtener un pronunciamiento judicial, y las eventuales consecuencias respecto del planteamiento de procedimientos posteriores ${ }^{21}$. Asimismo,

$20 \quad$ El Consejo de Estado se ha referido a esta dificultad en su Dictamen 692/2001 de 19 de abril, que aprecia que "Coincide el Consejo de Estado con el Consejo General del Poder Fudicial y con el órgano instructor en que en el asunto consultado se ha producido un evidente funcionamiento anormal de la Administración de fusticia. Por un lado, el proceso penal ha tenido una duración extraordinariamente prolongada, que excede ampliamente del plazo razonable; por otro, por una circunstancia imputable al órgano judicial (no proveer la personación de dos de los procesados), la Audiencia Provincial declaró la prescripción de la acción penal, porque, según su interpretación, el tiempo transcurrido desde la omisión viciada de nulidad (marzo de 1986) es considerado plazo de paralización del proceso a efectos de prescripción. Por consiguiente, el reclamante ha tenido que sufrir el perjuicio de una litispendencia indebidamente dilatada durante casi veinte años para al final perder toda acción penal por causa imputable a la Administración de fusticia”... "No es tarea fácil en este caso precisar la dimensión exacta del perjuicio derivado de ese funcionamiento anormal".

21 Así lo estima la SAN (Sala de lo Contencioso-administrativo) de 24 octubre 2002, según la cual: "Reconocida la existencia del funcionamiento anormal, la cuestión a enjuiciar queda limitada a determinar la indemnización que deba percibir el perjudicado. $Y$ a este respecto, es obligado advertir que los daños y perjuicios indemnizables han de ser los derivados del funcionamiento anormal, en razón a la necesaria relación de causalidad entre el irregular funcionamiento y el daño sufrido. En este sentido, los conceptos y cantidades indemnizatorios solicitados por el reclamante no son consecuencia directa del anormal funcionamiento de la Administración de Justicia ya que, para que ello fuera así, deberíamos tener la certeza de que, de 
se ha entendido que deben concretarse por el actor los daños materiales que pueden existir como consecuencia del mal funcionamiento de la Administración de Justicia, ya que una referencia a los daños derivados del mal funcionamiento sólo justifica el reconocimiento de daños morales que se suponen ${ }^{22}$.

También el Consejo de Estado ha tenido ocasión de pronunciarse sobre supuestos en los que, tras apreciar la pérdida de oportunidad procesal derivada del mal funcionamiento de la Administración de Justicia, distingue entre los daños derivados de la dilación indebida y los daños derivados del objeto del proceso principal en el que se produce el mal funcionamiento de la Administración de Justicia, considerando resarcibles únicamente los primeros, esto es, los que son consecuencia directa del funcionamiento de los servicios públicos ${ }^{23}$. Además, si se entendiera que queda expedita alguna vía jurisdiccional, y sólo en estos casos, cabría sostener la procedencia de una indemnización equivalente al perjuicio que supone promover un nuevo pleito para obtenerla ${ }^{24}$. A mayor abundamiento, el Alto órgano consultivo ha señalado en

haberse seguido debidamente las actuaciones penales, habrían concluido en un pronunciamiento condenatorio, y que dicho pronunciamiento habría conllevado a su vez una sentencia estimatoria ante la jurisdicción social. Es evidente que no puede partirse de dicho presupuesto como incuestionable. Por dicha razón, en supuestos como el que se examina, han de indemnizarse exclusivamente los daños morales consecuentes a la frustración del interés legítimo de la víctima en obtener un pronunciamiento penal, y las eventuales consecuencias respecto del planteamiento de procedimientos posteriores, conceptos que vienen siendo indemnizados por esta Sección en supuestos como el que se examina con una cantidad de 1.500 Euros, cantidad que ha de considerarse razonable también en el caso de autos".

22 STS (Sala de lo Contencioso-administrativo) de 4 de mayo de 2007.

23 Así, lo entiende el Dictamen del Consejo de Estado 1003/2010, de 23 de septiembre de 2010, que considera que "A estos efectos, es necesario diferenciar entre el daño resarcible como consecuencia del anómalo funcionamiento en los servicios de la Administración de Justicia y el fondo mismo de la cuestión debatida en el proceso judicial. Esto es, una cosa son los perjuicios -en este caso, la pérdida de oportunidad procesal- originados por la indebida dilación del procedimiento y otra cosa son los daños sufridos como consecuencia de la agresión sexual supuestamente padecida por su hïa menor. Sólo los primeros, es decir, los que son consecuencia directa del funcionamiento anormal de la Administración de Justicia son indemnizables en estos casos.

24 En este último sentido, resulta esclarecedor el Dictamen del Consejo de Estado núm. 722/2013, de 13 de septiembre, según el cual, "Se razona en la propuesta que, a consecuencia de la prescripción de la acción penal por dilaciones indebidas, la entidad reclamante ha sufrido un "perjuicio efectivo", consistente -según doctrina del Consejo de Estado- en la "pérdida del derecho a obtener en sede penal una resolución sobre la responsabilidad civil del acusado" y en el "deber de promover un pleito civil para obtenerla"... La paralización del procedimiento penal determinante de la prescripción de la acción no resulta, por tanto, imputable a las partes personadas sino a la inactividad del órgano jurisdiccional actuante, pues -como se dice en la sentencia de apelación- no se practicó diligencia alguna, ni se dictó resolución, durante un periodo de tiempo superior a seis meses. La prescripción de la acción penal se produjo, pues, a causa de un funcionamiento anormal de la Administración de fusticia, que ha impedido a la mercantil ahora reclamante recuperar la posesión de la nave en ejecución provisional del pronunciamiento civil en tal sentido contenido en la sentencia $n^{\circ} 155$ del Juzgado de Instrucción $n^{\circ} 5$ de A Coruña, de 25 de junio de 2009, y que le obligará a ejercer la correspondiente acción en vía civil -distinta de la demanda de desahucio en su día ejercitada- dirigida a recobrar dicha posesión, con el consiguiente coste que ello comporta. El perjuicio ocasionado a la mercantil interesada en el presente caso se contrae a la pérdida del derecho a obtener en sede penal la restitución de la posesión de la nave, que no puede cuantificarse, como ésta pretende en su reclamación, al valor de uso de la nave y de los bienes muebles en ella contenidos durante el tiempo de desposesión. En este punto, debe distinguirse entre el daño resarcible a título de funcionamiento 

terroristas-pérdida de oportunidad, prescripción y pervivencia de acciones civiles-

distintas ocasiones que la vía de la responsabilidad patrimonial del Estado no puede servir como un medio de resarcirse de los perjuicios ocasionados en el seno de un proceso judicial, de carácter alternativo a su exigencia frente a los verdaderos causantes de tales perjuicios (habitualmente, quien aparece como deudor en ese proceso), articulando una especie de responsabilidad subsidiaria (o incluso solidaria) del Estado por vía de responsabilidad patrimonial por funcionamiento de la Administración de Justicia"25.

Volviendo al asunto que nos ocupa, esto es, en el caso de extravío de expediente judicial, si de no haberse extraviado el mismo, con toda seguridad existe una razonable certidumbre de la probabilidad del resultado ${ }^{26}$, o lo que es lo mismo, una relación de certeza objetiva entre el mal funcionamiento de la Administración de Justicia y la frustración de las pretensiones del perjudicado, como señalábamos supra, deberá entonces indemnizarse la totalidad del perjuicio producido y no únicamente la pérdida de unas expectativas de obtenerlo, en aplicación de la doctrina del lucro cesante.

A mayor abundamiento, en el concreto caso de pérdida de expediente judicial sobre atentado terrorista, la frustración de la acción judicial como consecuencia de dicho extravío implica sin lugar a dudas la causación de un daño patrimonial, porque el objetivo de la acción frustrada consiste precisamente en la obtención de una ventaja de contenido económico. Ello lleva a la necesidad de llevar a cabo un cálculo

anormal de la Administración de fusticia, que es la pérdida de oportunidad procesal resultante de la prescripción de la acción penal, de aquellos otros que le hayan sido ocasionados a ..., por la pérdida de posesión del referido inmueble y de los objetos existentes en su interior, que serán únicamente reclamables al propietario, como autor del despojo posesorio, en el supuesto de que la jurisdicción civil considere que éste ha actuado ilícitamente. Por esta razón, no puede indemnizarse con un importe equivalente al valor de uso de la nave y de los bienes muebles en ella radicados durante el tiempo de desposesión, máxime cuando la restitución de la finca ordenada en sentencia $n^{\circ} 155$ del Juzgado de Instrucción $n^{\circ} 5$ de A Coruña, de 25 de junio de 2009, constituía un pronunciamiento que, aun siendo ejecutable provisionalmente, no habia ganado firmeza. El único concepto indemnizable a título de responsabilidad patrimonial por funcionamiento anormal de la Administración de Justicia debe ser, en el presente caso, en el coste del proceso civil que la entidad reclamante deberá promover en orden a recuperar la posesión de la nave y de los bienes muebles que en ella se encuentran. La jurisprudencia del Tribunal Europeo de Derechos Humanos así lo viene entendiendo, en el marco normativo del artículo 50 del Convenio Europeo para la Protección de los Derechos Humanos y de las Libertades Fundamentales, y tal criterio ha sido recogido por la doctrina del Consejo de Estado en anteriores ocasiones (dictamen $n^{\circ} 879 / 2006$, de 29 de junio)".

25 Vid. Dictámenes del Consejo de Estado núm. 692/2005 y 1108/2006. Entiende el Alto órgano consultivo que el Consejo General del Poder Judicial ha apreciado un funcionamiento anormal de la Administración de Justicia, en razón del extravío de actuaciones judiciales, del plazo excesivamente largo para resolver un proceso (quince años desde que se interpone la demanda hasta que se resuelve el procedimiento ejecutivo), de los retrasos en la notificación de actuaciones judiciales y de la consiguiente pendencia durante once años de un proceso penal contra el reclamante, que había sido sobreseído y de cuyo auto de sobreseimiento se demoró la notificación del Juzgado al querellante durante un plazo de tres años. Pues bien, considera el Consejo de Estado que "Ia evidencia del funcionamiento anormal de la Administración de Fusticia no determina, por sí, la procedencia de indemnizar al reclamante, sino que para ello resulta necesario constatar que dicho funcionamiento anormal le ha producido un perjuicio efectivo, evaluable económicamente e individualizado".

26 Vid. STS (Sala de lo Contencioso-administrativo) de 27 de julio de 2006. 
prospectivo de la indemnización a la que se tuvo derecho, incrementada por el interés legal del dinero, además de los correspondientes daños morales. En efecto, la pérdida del expediente a cuyo contenido no se puede acceder genera una pérdida de oportunidad cierta o lucro cesante como daño indemnizable que constituye un claro supuesto de funcionamiento anormal del Poder Judicial. Y es que, en el sentido apuntado, el TS ha considerado oportuno entrar a valorar la verosimilitud de la oportunidad perdida, cuando fuera claro o evidente que cualquier otro juzgador habría llegado a la misma conclusión de que si se hubiera podido ejercer la parte sus derechos eficazmente, el fallo en el pleito hubiera sido ese (estimatorio o desestimatorio de la pretensión del perjudicado). Advirtiendo que, si bien no se debe establecer un rígido mimetismo entre la pretensión planteada en el procedimiento en que se dio la actuación culposa y los daños y perjuicios a indemnizar, como si se tratara de una especie reflejo mecánico de la pretensión que en su día no pudo ejercitarse conforme al derecho a la tutela judicial efectiva, cuando el triunfo del pleito pasa de ser una posibilidad a un hecho cierto, entonces debe reconocerse la plena satisfacción de la pretensión ${ }^{27}$.

Y en el concreto caso que nos ocupa, da la casualidad de que la pérdida de oportunidad procesal genera una responsabilidad patrimonial del Poder Judicial respecto de un derecho subjetivo ejercitable frente al propio Estado, pues este responde de los daños derivados de atentado terrorista ${ }^{28}$. Así, en virtud de dicho mal funciona-

27 Vid. STS (Sala de lo civil) no 303/2009, 12 de mayo de 2009 (f. j. 5). Advierte el TS que "La segunda postura jurisprudencial tampoco es atendible. No se puede tener como base para determinar la existencia del daño o su valoración económica la prosperabilidad o no de las pretensiones de la actora. Si así se hiciera se entraría en el ámbito de las conjeturas y expectativas de derechos, las cuales, obviamente, no pueden ser valoradas y mucho menos objeto de debate en una resolución judicial, ni siquiera como mera hipótesis. La existencia de una responsabilidad civil dependería de una revisión "a posteriori" de un proceso judicial y a finalizado en firme y que por efecto del principio de la cosa juzgada no es posible revivir, siendo evidente que esta labor no tendría amparo en un cauce jurídico válido. $Y$ ni siquiera para valorar el "quantum" indemnizatorio pues, si en los daños morales no se parte para su valoración de unas pautas objetivas y determinadas, como se verá más adelante, sino de un criterio subjetivo del juzgador atendiendo a las circunstancias concurrentes, si el punto de partida de este análisis subjetivo fuera a su vez el estudio de la prosperabilidad de las pretensiones del actor en un pleito en el que la decisión no depende de este juzgador, no pudiéndose "prejuzgar" el mismo, en puridad para ver esa probabilidad de éxito debería ponerse en lugar del juez de aquel pleito, con la visión particular que pueda tener este de las cosas tanto a nivel jurídico como personal, cosa que se antoja imposible y que, en todo caso, nos situaría al calcular el daño moral en por llamarlo de alguna manera, la "subjetividad de la subjetividad". Por tanto, se entiende que solo se podría acudir a este criterio en supuestos excepcionales cuando fuera tan claro o evidente, llevando a la certeza a este juzgador, que cualquier otro habría llegado a la misma conclusión de que si se hubiera podido ejercer la parte sus derechos eficazmente, el fallo en el pleito hubiera sido ese (estimatorio o desestimatorio de la pretensión del perjudicado), no pudiendo hablarse de más o menos probabilidades en un sentido u otro.

28 Por lo que se refiere al marco normativo del deber estatal de resarcir los daños causados por grupos o bandas armadas, el primer antecedente que encontramos, relativo al establecimiento de obligaciones a cargo del Estado para la atención de las víctimas del terrorismo, se encuentra en el Decreto-Ley 10/1975, de 26 de agosto, sobre prevención del terrorismo, derogado por el Real Decreto-Ley 3/1979, de 26 de enero, de Seguridad Ciudadana. En tal texto legal se partía de un supuesto restrictivo para el otorgamiento 
miento del Poder Judicial se produce un daño efectivo, individualizado y evaluable económicamente, que se corresponde con la indemnización a que ha lugar en virtud del proceso principal, por lo que el perjuicio a resarcir, como sucede al aplicar la doctrina del lucro cesante, debe ser en estos casos la cuantía a la que asciendan los daños causados por el propio hecho que dio lugar a la incoación del proceso cuyo expediente se ha extraviado. El Estado, pues, por determinación legal sí que debe hacerse cargo de la indemnización que correspondería satisfacer al verdadero deudor, por lo que sí procedería articular una suerte de responsabilidad subsidiaria del Estado en supuestos de pérdida de expedientes judiciales sobre atentados terroristas.

En conclusión, la pérdida del expediente judicial debe considerarse como un supuesto de funcionamiento anormal de la Administración de Justicia. Y de la pérdida del expediente debe nacer el derecho a la indemnización pues concurren el resto de presupuestos exigidos legalmente, en concreto, la producción de un daño efectivo que el particular no tiene el deber jurídico de soportar y el nexo causal entre el perjuicio sufrido y la actuación de la Administración ${ }^{29}$. En efecto, no habrá sido posible el consiguiente reconocimiento judicial del derecho a percibir una indemnización en concepto de responsabilidad civil derivada de delito, más los intereses legales correspondientes como consecuencia del extravío del expediente. Asímismo dicha pérdida del expediente, además de este daño patrimonial, genera daños morales que también deben ser resarcidos ${ }^{30}$. Y ello porque, como es sabido, de conformidad con los arts.

de tales indemnizaciones, toda vez que sólo estaban encaminadas a la reparación de aquellos daños que se causaran especialmente a funcionarios y particulares con ocasión de su actividad o colaboración para la prevención o represión de los hechos delictivos referidos en la misma norma, que no eran otros que los actos de terrorismo. Posteriormente, se sucedieron una serie de normas que fueron avanzando en las garantías indemnizatorias, concretamente el Real Decreto Ley 3/1978 por los Acuerdos del Consejo de Ministros de 16 de marzo de 1979 y 25 de marzo de 1983, Real Decreto Ley 3/1979, de 26 de enero, de Seguridad Ciudadana: el Real Decreto 484/1982, de 5 de marzo, La Ley Orgánica 9/1984, de 26 de diciembre, contra la actuación de bandas armadas y elementos terroristas y el Real Decreto 336/1986, de 24 de enero, sobre indemnizaciones a las víctimas de las bandas armadas y elementos terroristas, las Leyes 33/1987, de 23 de diciembre, 4/1990, de 29 de julio y 31 / 1991, de 30 de diciembre de Presupuestos Generales del Estado, Ley 35/1995, de 11 de diciembre, de ayudas y asistencia a las víctimas de delitos violentos y contra la libertad sexual, hasta llegar a la Ley 32/1999, de 8 de octubre, de Solidaridad con las víctimas del terrorismo y los Reales Decretos 1912/1999, de 17 de diciembre y 288/2003, de 7 de marzo.

29 Vid. Dictamen del Consejo de Estado núm. 3126/2001, de 31 de enero de 2002.

30 Deben tenerse en cuenta las dificultades que entraña, además de su definición, la prueba de los daños morales, aunque es cierto que la jurisprudencia relaja considerablemente su exigencia cuando de los hechos que constan se infiere claramente la concurrencia del daño. Vid., en este sentido, Dictamen del Consejo de Estado núm. 93/2007, de 1 de marzo de 2007. También la cuantificación del daño moral resulta ser una cuestión problemática, por el marcado carácter subjetivo de los derechos vulnerados, por lo que la jurisprudencia tiene en cuenta la gravedad de los hechos, su entidad real o potencial, la relevancia y repulsa social de los mismos, así como las circunstancias personales de los ofendidos, y por razones de congruencia, las cantidades solicitadas por las acusaciones (STS de 12 de mayo de 2000, de 29 de mayo de 2000, de 29 de junio de 2001 y de 3 de enero de 2003). 
109 y siguientes, y en especial el art. 116 CP, "toda persona criminalmente responsable de un delito o falta lo es también civilmente si del hecho se derivan daños o perjuicios", "viniendo obligado a reparar en los términos previstos en las Leyes aquéllos por él causados". Y dada la naturaleza de la acción delictiva que nos ocupa, la indemnización no puede obedecer a otra causa que a los daños morales producidos a las víctimas ${ }^{31}$.

\section{Vulneración de la tutela judicial efectiva por extravío de expediente judicial}

A la vista de todo lo expuesto, y en la medida en que la pérdida del expediente judicial supone a todas luces la frustración de la acción, debemos preguntarnos entonces si en estos casos la actuación del Poder Judicial - por acción u omisión- vulnera el derecho fundamental a una tutela judicial efectiva, lo cual, en caso afirmativo, permitiría invocar en el procedimiento de responsabilidad patrimonial que se sustanciara la vulneración de los derechos fundamentales.

Debe señalarse que, en relación con las dilaciones indebidas, que es uno de los casos más frecuentes de responsabilidad del Poder judicial, pero también predicable en relación con el extravío de expedientes judiciales, el TG en STG 5/1985, de 23 de enero ha invocado la aplicación del art. 6 de la $\mathrm{CEDH}$, que establece el derecho a que la causa sea vista en un "plazo razonable" o, como advierte el art. 24.2 CE "sin dilaciones indebidas". La jurisprudencia del TEDH ha ido perfilando una serie de criterios interpretativos sobre el referido "plazo razonable" al que se refiere el art. 6 del CEDH, como la complejidad del litigio, la conducta de los litigantes, las consecuencias que pueden derivar de la demora para las partes y los márgenes ordinarios en los tipos de procesos de que se trata ${ }^{32}$. Asimismo, el TC ha entendido que el retraso causado por el extravío del expediente o la inactividad de la Sala para suplirlo, ha de considerase excesivo respecto al tiempo razonable en que debe desarrollarse un proceso ${ }^{33}$ y, trayendo a colación la STEDH, de 23 de abril de 1977 (asunto König), manifiesta que esto afecta al derecho del recurrente a obtener la tutela efectiva de los Jueces y Tribunales dentro de unos límites temporales adecuados ${ }^{34}$.

31 Vid. STS (Sala de lo Contencioso-administrativo) núm. 376/2004, de 17 de marzo y SAN (Sala de lo Penal) núm. 60/2006, de 8 de noviembre.

32 En este sentido, vid. STEDH de 6 de mayo de 1981 (caso Buchholz). En parecidos términos se expresa la STEDH de 13 de julio de 1983 (caso Zimmermann y Steiner), asumiendo la doctrina de los asuntos König, Guzzardi, Buchholz, Foti, Corigliano y Mineli.

33 STC 18/1993, de 14 de marzo.

34 A pesar de lo anterior, debe tenerse presente que el derecho a ser indemnizado por dilaciones indebidas no es en sí mismo un derecho invocable en la vía de amparo. Como ya señaló la STC 36/1984, de 14 de marzo, el pronunciamiento del TC ha de limitarse a declarar la existencia de la lesión del derecho constitucionalmente garantizado y la conexión entre tal lesión y el supuesto contemplado en el art. 121 CE, 

terroristas-pérdida de oportunidad, prescripción y pervivencia de acciones civiles-

En consonancia con lo anterior, el daño objetivo que implica impedir ejercer una acción legítima y la privación que para el perjudicado supone la posibilidad de éxito del derecho a indemnización derivado de la responsabilidad por acto terrorista, genera una vulneración en su derecho a la tutela judicial efectiva, en sus legítimas expectativas en el proceso y en la satisfacción del derecho a la verdad. De este modo, en caso de estimarse, debería tenerse en cuenta, además del daño moral genérico, y la vulneración del derecho fundamental a la tutela judicial efectiva. Porque los poderes públicos tienen la obligación de respetar, proteger y materializar el derecho de las víctimas de violaciones de derechos humanos, como es el caso de un atentado terrorista, a interponer recursos efectivos frente a tales vulneraciones ${ }^{35}$.

En este sentido se ha pronunciado el TEDH al reconocer que en casos en los que cabe apreciar una violación grave de los derechos humanos, "la respuesta adecuada de las autoridades es esencial para preservar la confianza del público en el respeto del principio de legalidad y evitar cualquier apariencia de complicidad o tolerancia en relación con los actos ilícitos ${ }^{96}$.

sin perjuicio de que, a partir de ello, el lesionado procure, a través de otras vías, el resarcimiento. Para ello, pues, sería necesario agotar todas las vías ordinarias.

35 Así queda reconocido en el art. 8 de la Declaración Universal de Derechos Humanos, el art. 2.3 del Pacto Internacional de Derechos Civiles y Políticos y en el art. 13 del Convenio Europeo de Derechos Humanos, entre otros tratados internacionales. En el caso de extravío de expedientes relativos a atentados terroristas, el comportamiento de la Administración de Justicia conculca, pues, derechos de los recurrentes como el derecho a la verdad, a la tutela judicial efectiva y a la reparaciónLas Resoluciones 9/11 y 12/12 Derecho a la Verdad, aprobadas el 24 de septiembre de 2008 y el 12 de octubre de 2009 por el Consejo de Derechos Humanos de las Naciones Unidas, advierten que El Comité de Derechos Humanos ha reconocido que las víctimas de violaciones graves de los derechos humanos y sus familiares tienen derecho a conocer la verdad sobre los hechos ocurridos, incluido el conocimiento de la identidad de los autores de los hechos que dieron origen a estas violaciones (...). En el mismo sentido, deben consultarse las Directrices del Comité de Ministros del Consejo de Europa sobre la erradicación de la Impunidad de las Violaciones Graves de los Derechos Humanos, 30 de marzo de 2011, según las cuales "la impunidad de los responsables de actos que constituyen graves violaciones de los derechos humanos, añade dolor a las víctimas». En esta línea, el que un recurso y una indemnización adecuados implican que las víctimas de presuntas violaciones de los artículos 3 y 5 del Convenio sean reconocidas como tales y gocen del debido respeto, para que ellas mismas, sus familias y el conjunto de la sociedad puedan conocer la verdad sobre las violaciones sufridas. Si bien, además de la indemnización, habría que procurar otros elementos fundamentales para la función de reparación a largo plazo que desempeña la indemnización, concretamente el reconocimiento público de la verdad y el hecho de actuar adecuadamente, mediante una forma $u$ otra de reparación, del calvario que ha atravesado la víctima, constituye un paso esencial en la curación del superviviente. Si la verdad permanece oculta y los autores quedan impunes, se exacerba el sentimiento de impotencia del superviviente y su dificultad para dar sentido a lo que ha vivido y pasar página".

36 Vid., STEDH de 24 de mayo de 2011. En el mismo sentido, según las Directrices de 30 de marzo de 2011 del Consejo de Europa, "Los Estados tienen el deber de luchar contra la impunidad, al objeto de hacer justicia a las víctimas, disuadir de la comisión ulterior de violaciones de los derechos humanos y preservar el Estado de Derecho y la confianza de la opinión pública en el sistema judicial”. 


\section{PRESGRIPGIÓN DE LA ACGIÓN DE RESPONSABILIDAD POR PÉRDIDA DE EXPEDIENTE JUDICIAL. SOBRE LA DETERMI- NACIÓN DEL DIES A QUO}

Volviendo al sistema de responsabilidad del Poder Judicial diseñado por la LOPJ, y en relación ahora al plazo de reclamación, el dies a quo se inicia en el momento en que puede ejercitarse la acción, es decir, cuando concurren ya todos los requisitos que hacen viable la acción (art. 293.2 LOPJ).

En principio, en un caso como el que nos ocupa, en el que el ejercicio de la acción indemnizatoria se efectúa sobre la base de la existencia de un funcionamiento anormal en el proceso penal -del que ha derivado la pérdida del expediente judicial-, dicho plazo ha de comenzar a computarse a partir del día en que la parte tuviera conocimiento de tal funcionamiento anormal y de las dimensiones fácticas y jurídicas del alcance de los perjuicios producidos.

Sobre el dies a quo en estos casos es constante la jurisprudencia al otorgar relevancia al momento en que se comprueba la ilicitud del daño ${ }^{37}$, situando el mismo en el momento en que se comprueba la ilicitud del daño ${ }^{38}$. Del mismo modo la juris-

\footnotetext{
37 Sobre un asunto sobre responsabilidad del Estado Juez, y en apoyatura de este entendimiento de la prescripción de la acción responsabilidad por pérdida de expediente, debe traerse a colación el Dictamen del Consejo de Estado, núm. 2542/2006, de 1 de marzo de 2007, según el cual “... la conclusión que se alcanza en este informe debe ser favorable a dicha pretensión, toda vez que el hecho del extravío queda perfectamente acreditado en los autos, así como su incidencia directa en la demora de tramitación sufrida por la actividad procesal penal (...) El retraso no puede entenderse imputable, desde el punto de vista de la responsabilidad patrimonial por funcionamiento anormal de la Administración de Justicia, al comportamiento de la reclamante, pues ni fue ella la responsable del extravío del expediente, ni es ella la responsable, por la naturaleza indisponible de los derechos que se sustancian en el proceso penal-incluido el de faltas-de dicho retraso: ni la ley le exige que sea ella quien incoe el procedimiento penal por faltas en supuestos como el analizado, ni tampoco que se constituya como parte del procedimiento (...)., por lo que no es de recibo entender que debió ser la ahora reclamante quien asumiera una carga de impulso procedimental que la ley no le atribuye. La reclamante no fue, en resumen, la responsable del hecho causal del retraso y, por esa razón, no la pueden perjudicar las consecuencias de un hecho que no se debió a su comportamiento sino, como queda acreditado, al funcionamiento anormal de un órgano jurisdiccional".

${ }_{38} \quad$ Así, la STS (Sala de lo Contencioso-administrativo) de 11 noviembre 2010, advierte que "Fue precisamente la resolución del Tribunal Supremo la que marcó el día a quo del cómputo del plazo de prescripción para el ejercicio de la acción en vía administrativa de acuerdo con la propia jurisprudencia de esta Sala, al implicar la citada sentencia el momento en que se comprueba la ilicitud del daño padecido. Si bien es cierto que el recurso de casación en interés de ley fue interpuesto, como así lo exige el ordenamiento jurídico, por el Ministerio Fiscal y no por el demandante, que carecía de legitimación para su interposición, éste compareció en dicho proceso, como también pone de relieve el Tribunal de instancia, en calidad de parte recurrida, demostrando así una presencia que impide hablar de desinterés, pasividad, inactividad o silencio de dicha parte; si bien es cierto que la citada sentencia no altera la situación jurídica creada por el fallo que se enjuicia, si hace evidente y palmaria la ilicitud de la situación creada y, consiguientemente, del daño producido por la misma, marcando así el hito temporal a tener en cuenta para el inicio del cómputo del plazo de prescripción. Lo anterior queda ratificado, como constató el Tribunal de instancia, por la aplicación al caso del principio in dubio pro actione como parte consustancial del derecho a la tutela judicial efectiva, y por el carácter restrictivo que ha de predicarse del instituto de la prescripción". Y, por su parte, la STS (Sala de lo Contencioso-administrativo) de 19 enero 2015, según la cual "El artículo 293.2 de la LOPf establece, para ambos supuestos de error judicial y funcionamiento anormal de la Administración de Justicia, que el derecho a reclamar la
} 
prudencia de la Audiencia Nacional considera que el plazo del año de prescripción para el ejercicio de la acción de reclamación debe computarse a partir de la fecha en que concluyeron las actuaciones judiciales que ocasionaron el presunto daño al recurrente ${ }^{39}$.

En casos de pérdida de expediente judicial sobre atentado terrorista, en ningún caso puede entenderse superado el plazo prescriptivo, pues sólo a resultas del análisis del expediente judicial sobre el que se requiriera copia y no se obtuviera por encontrarse extraviado sería posible comprobar o constatar el funcionamiento que reputamos anormal y el daño antijurídico que ocasiona.

indemnización prescribirá al año, a partir del día en que pudo ejercitarse, y la sentencia recurrida sitúa el momento inicial del cómputo del plazo de prescripción en la fecha de notificación de la sentencia de la Sala de lo Penal del Tribunal Supremo, de 29 de julio de 1998, que era firme y no admitía recurso alguno, con la consecuencia de considerar que, en la fecha de presentación de la reclamación de responsabilidad ante el Ministerio de Fusticia, el 16 de abril de 2009, se había completado el plazo de prescripción". La STS (Sala de lo Contencioso-administrativo) núm. 1290/2016, de 2 junio, para la que "El día inicial del plazo anual de prescripción se rige por el principio de la actio nata, siendo así que en el caso el dictamen del Consejo de Estado reconoce que el recurso de casación ante el Tribunal Supremo contra la sentencia dictada en apelación por la Audiencia Provincial de Santa Cruz de Tenerife interrumpió el meritado plazo de prescripción...”.

39 Vid. SAN (Sala de lo Contencioso-administrativo) de 19 noviembre 2002, que aplica la jurisprudencia del TS en el cómputo del plazo de prescripción del año a partir del día en que pudo ejercitarse, de conformidad con el art. 293.2 LOPJ, esto es, a partir del día de la firmeza, que la sentencia de la Audiencia Nacional computa desde la notificación al procurador; SAN (Sala de lo Contencioso-administrativo), de 23 mayo 2002 "el procedimiento penal que fundamenta la reclamación del recurrente, concluyó respecto del mismo por auto del Juzgado de Instrucción $n^{\circ} 8$ de L'Hospitalet de fecha 18 de febrero de 1998, resolución judicial que acordó el sobreseimiento libre de la causa. El referido auto judicial fue notificado al Procurador del actor el día 23 de febrero siguiente... Consecuentemente, a partir de dicha fecha empezó a computarse el plazo para el ejercicio de la reclamación por el funcionamiento de la Administración de fusticia"; SAN (Sala de lo Contencioso-administrativo) de 31 mayo 2002, según la cual, "En el presente caso la sentencia absolutoria es de 12 de Diciembre de 1997, notificada a la recurrente ese mismo día, en que fue puesta en libertad; por lo tanto sería a partir de esta fecha, en que ya el daño estaba perfectamente concretado ... ésta no puede ejercitarse sino desde el momento en que resulta posible por conocerse en sus dimensiones fácticas y jurídicas el alcance de los perjuicios producidos. Esta doctrina tiene su origen en la aceptación por este Tribunal (sentencias de la Sala Tercera de 19 de septiembre de 1989, 4 de julio de 1990 y 21 de enero de 1991) del principio de «actio nata» (nacimiento de la acción), según el cual el plazo de prescripción de la acción comienza en el momento en que ésta puede ejercitarse, y esta coyuntura sólo se perfecciona cuando concurren los dos elementos del concepto de lesión, es decir, el daño y la comprobación de su ilegitimidad»; SAN (Sala de lo Contencioso-administrativo), de 7 diciembre 2005 "En todo caso, y cualquiera que sea el fundamento de la responsabilidad por funcionamiento anormal de la Administración de Fusticia, de conformidad con el art.293.2 LOPJ, el derecho a reclamar prescribe en el plazo de un año, a partir del día en que pudo ejercitarse. ... el plazo del año de prescripción para el ejercicio de la acción de reclamación debe computarse a partir de la fecha en que concluyeron las actuaciones judiciales que ocasionaron el presunto daño al recurrente, es decir, desde la fecha de la sentencia de la Sala de lo Contencioso-Administrativo de la Audiencia Nacional de 21 de octubre de 1999 que declaró la inadmisibilidad del recurso contencioso-administrativo formalizado por el recurrente"; y, entre, otras la SAN (Sala de lo Contencioso-administrativo) de 28 febrero 2007, según la cual "Cuestión distinta es que todas estas actuaciones tendentes a la localización de las Diligencias Previas o a su reconstrucción se hubieran iniciado dentro del año siguiente al conocimiento de tal funcionamiento anormal y de las dimensiones fácticas y jurídicas del alcance de los perjuicios producidos, pues en este caso, en la medida que las referidas peticiones eran idóneas para reponer los daños sufridos, por manifestar inequívocamente una voluntad en tal sentido y ser dirigida a un órgano adecuado, entendiendo ésta en sentido amplio, entenderíamos interrumpido el plazo de prescripción". 
Cuestión distinta, en cambio, sería que las eventuales actuaciones tendentes a la localización de las diligencias o a su reconstrucción, en su caso, se hubieran iniciado dentro del año siguiente al conocimiento de tal funcionamiento anormal y de las dimensiones fácticas y jurídicas del alcance de los perjuicios producidos pues, en este caso, en la medida que las referidas peticiones eran idóneas para reponer los daños sufridos, por manifestar inequívocamente una voluntad en tal sentido y ser dirigidas a un órgano adecuado, entenderíamos entonces interrumpido el plazo de prescripción.

\section{LA EVENTUAL PERVIVENGIA DE LAS ACGIONES CIVILES DERIVADAS DEL ATENTADO EN SUPUESTOS DE EXTRA- VÍO DEL EXPEDIENTE JUDICIAL}

\section{Pervivencia de la acción en casos de sobreseimiento provisional no notificado al ofendido}

Como se ha tenido ocasión de argumentar, procede reclamar al Estado los daños por pérdida de oportunidad o por lucro cesante derivados de la pérdida de expedientes judiciales por atentados terroristas que se encuentran extraviados. Ahora bien, nos preguntamos ahora si es posible el ejercicio de la acción civil derivada de la causa principal, esto es de aquella que fue objeto de pérdida o extravío. Veamos a continuación cuál es la situación procesal de estas acciones.

En casos de atentado terrorista el plazo para reclamar el resarcimiento de los daños y perjuicios irrogados no empieza a computarse hasta la finalización del proceso penal seguido por el atentado o, dicho de otro modo, las actuaciones judiciales penales interrumpen el plazo de prescripción de la acción civil derivada del delito, ya se trate de actuaciones sumariales, ya se trate de diligencias de averiguación. Cuando nos encontramos ante expedientes judiciales por atentados terroristas extraviados pueden constar o no las diligencias de ofrecimiento de acciones que, como es sabido, abren una vía a la personación del ofendido como acusador particular en un proceso ya iniciado por otro acusador, en este caso por el Ministerio Fiscal (arts. 109 y 761 LECr). Sobre este extremo, la STS(Sala de lo Penal) de 22 de septiembre de 2006 ha entendido que, si el ofrecimiento de acciones no se hizo, nos encontraríamos ante un incumplimiento por parte del juez competente, del que se derivaría, a su vez, responsabilidad del Poder judicial, cuestión, ésta, que pasaría a discutirse en el caso de que apareciera el expediente. Ahora bien, en el caso de que, a pesar de haberse omitido dicho ofrecimiento de acciones, se hubiera personado el ofendido, se habría subsanado dicho defecto por la personación. 

terroristas-pérdida de oportunidad, prescripción y pervivencia de acciones civiles-

Pero es cierto que precisamente como consecuencia del extravío del expediente, no suele constar si tuvo lugar o no el ofrecimiento de acciones. Más aún en el caso de haberse producido dicho ofrecimiento, se limitaba de ordinario a recabar la firma del ofendido los días posteriores al atentado, sin que fuera consciente el mismo del alcance para sus derechos de dicho ofrecimiento, circunstancia que, dicho sea de paso, no debe afectar a la pervivencia de las acciones civiles. Pues bien, la falta de personación en el proceso penal por omisión del ofrecimiento de acciones implica la falta de notificación de actuación procesal alguna en el seno del proceso penal cuyo expediente se ha extraviado, incluido el eventual auto de sobreseimiento que pudiera haberse dictado si es que fuera esta la forma de terminación del proceso penal controvertido. Debe tenerse en cuenta que el ordenamiento jurídico no contemplaba, a diferencia de lo que sucede a día de hoy, la notificación al ofendido de las diversas actuaciones procesales, incluidos los autos de sobreseimiento o la eventual sentencia (arts. 789.4 y 792.4 LECr) y que, en consecuencia, no existiendo notificación no cabe la reanudación del cómputo del plazo de prescripción de la acción civil derivada del delito terrorista.

En relación con lo anterior, y en el caso de personación del ofendido, éste pudo reservarse el ejercicio de las acciones civiles para entablar un procedimiento ante dicha jurisdicción, ventilándose entonces ante la Jurisdicción penal únicamente la acción para la persecución del delito, quedando expedita la vía civil resarcitoria. El procedimiento civil independiente no podría iniciarse hasta que recayera sentencia firme en la causa penal (arts. 111 y 112 LECr), teniendo en cuenta, además, que el ofendido o perjudicado puede renunciar al ejercicio de la acción civil. Y no podría darse eficacia a una presunta renuncia tácita, o a manifestaciones de voluntad de los perjudicados que no resultaran terminantes, si es que la Administración de Justicia opusiera estas circunstancias, de aparecer el expediente judicial extraviado (art. 112 LECr $)^{40}$.

Sentado lo anterior, interesa analizar ahora la eventual pervivencia de las acciones civiles derivadas del atentado en el caso de haberse producido un archivo de la causa mediante auto de sobreseimiento provisional no notificado a los ofendidos, y en tanto en cuanto se desconocieran los motivos de dicho sobreseimiento, que suele

\footnotetext{
40 En este sentido se pronuncia de forma reiterada la Jurisprudencia, especialmente la STS (Sala de lo Penal) de 27 de abril de 2006, al sostener que "En cuanto a lo alegado por Sergio en su motivo 2, en el que se dice que debió aplicarse el artículo 106 Ley de Enjuiciamiento Criminal, porque tenía que haberse entendido que D. Alonso habia renunciado a su derecho a ser indemnizado por no haber comparecido en el juicio oral, pese a estar citado, y por no haber reclamado nada al respecto en ningún momento del procedimiento en el cual ni siquiera se personó como parte, entendemos que en este punto tiene razón el Ministerio Fiscal, pues el artículo 108 obliga a tal ministerio a ejercitar la correspondiente acción civil respecto de cada uno de los ofendidos, salvo renuncia expresa, que desde luego nunca se produjo por parte de D. Alonso ni de ninguna de las otras dos personas perjudicadas".
} 
ser la situación en la que se encuentran un importante número de los expedientes extraviados ${ }^{41}$.

Debe partirse de que los autos que acuerdan el sobreseimiento provisional o el sobreseimiento libre o definitivo vienen a manifestar la terminación del proceso penal. No obstante, la diferencia entre ambos sobreseimientos radica en la extinción o no del proceso, puesto que en el caso de sobreseimiento provisional, ésta no es definitiva y sí lo es en el libre ${ }^{42}$. Así, una vez acordado el sobreseimiento provisional es posible reiniciarlo cuando el juez o el fiscal lo consideren conveniente y siempre que aparezcan nuevos elementos fácticos que así lo justifiquen ${ }^{43}$. Aunque el sobreseimiento reviste la forma de auto (arts 245.1.b LOPJ y 141 LEGr) y no de sentencia, el órgano jurisdiccional ha de plasmar los elementos de convicción en base a los cuales infiere la conclusión en torno a la ausencia del o de los presupuestos que impiden la apertura del juicio oral ${ }^{44}$.

Por lo que hace al derecho a la tutela judicial efectiva (art. 24.1 CE), ésta queda perfectamente salvaguardada cuando el proceso finaliza por auto de sobreseimiento, tal y como ha sido visto por el $\mathrm{TC}^{45}$. Y desde que el sobreseimiento deviene firme,

${ }^{41}$ Téngase en cuenta que, a día de hoy, en cambio, el sobreseimiento debe ser comunicado a la víctima del delito, aun cuando no se hubiera personado en la causa (art. 636 LECrim).

${ }^{42}$ Vid., CACHÓN CADENAS, M., "Efectos del sobreseimiento", Revista de Derecho procesal, núm., 3-4, 2008, p. 117.

43 Vid., SEGRELLES DE ARENAZA, "Sobreseimiento provisional, reapertura del proceso y derechos fundamentales", Cuadernos de Política Criminal, núm. 54, Madrid, 1994, p. 1060. Ahora bien, si bien es cierto que tras los autos de sobreseimiento provisional los órganos judiciales pueden volver a conocer "sobre lo mismo", puesto que no se ha dado una respuesta definitiva sobre la acción penal, sí que opera una limitación de naturaleza similar al non bis in idem en el seno del proceso, que determina que éste pueda reabrirse únicamente sobre la base de "algo distinto". A esta eficacia parece referirse el Tribunal Supremo en su STS de 30 de junio de 1997 cuando, reaccionando ante una injustificada reapertura de la causa por parte del Tribunal, afirma que con esta actitud se "desconoce el efecto de cosa juzgada que tiene el auto de sobreseimiento provisional en lo que concierne a la suficiencia de los elementos de comprobación obrantes en la causa para continuar con el proceso". Así pues, puede afirmarse que el efecto de la cosa juzgada formal determina los presupuestos que hacen posible la reapertura de las causas, garantizando de este modo que el estado en que permanezca el proceso tras estas resoluciones goce de cierta estabilidad, mientras no haya una razón suficiente que la enerve.

44 Sobre la necesidad de fundamentación de los autos de sobreseimiento, vid. las SsTC 173/1987, de 3 de noviembre, 171/1988, de 30 de septiembre, 36/1989, de 14 de febrero, y STS, de 12 de noviembre de 1991, entre otras).

45 SsTC 46/1982, de 12 de julio, 34/1983, de 6 de mayo y 62/1984, de 21 mayo. La STC 62/1984 advirtió que "tampoco se puede impugnar constitucionalmente la resolución judicial por el hecho de que en actuaciones de naturaleza penal se produzca una resolución de sobreseimiento, siempre que se hayan respetado las garantías procesales que incluye el agotar los medios de investigación procedentes". No obstante, debe señalarse que el TC exige que el sobreseimiento se base en alguna de las causas previstas en la Ley para que no se vulnere el derecho de tutela judicial efectiva (STC 171/1988, de 30 septiembre y 138/1986, de 7 de noviembre, en cuanto al archivo de diligencias del art. 789 LECr.). En este sentido, ha puntualizado que "si bien la forma prioritaria de satisfacción del derecho a la tutela judicial es la sentencia de fondo, que se pronuncie y decida sobre las pretensiones de las partes del proceso, 
deja expedito el ejercicio de la acción civil que estuvieren pendiente de una respuesta en el orden penal.

Dicho lo anterior, y en relación con la pervivencia o prescripción de las acciones civiles, como ha reconocido la STS (Sala de lo Contencioso-administrativo) de 7 de octubre de 2013, una vez acordado el sobreseimiento provisional, el plazo de prescripción de las acciones, cuando las partes están personadas en el procedimiento, empezará a contarse desde el día en que pudieron ejercitarse. En el caso resuelto por esta Sentencia, tras haberse dictado el auto de sobreseimiento de la causa penal, no hubo actividad judicial alguna, sin que la falta de notificación del mismo en forma sea impedimento para que el plazo de prescripción discurra, siempre que quede constancia que el interesado conoció por otras vías el contenido de la resolución judicial de archivo. La clave, pues, para la pervivencia de las acciones civiles es la constancia del conocimiento del contenido de la resolución judicial de archivo. También la STS (Sala de lo Contencioso-administrativo) de 16 de junio de 2010, dictada en relación a la notificación de una resolución penal, declaró que lo relativo a la incorrección o irregularidad en que puede haberse incurrido por el Juzgado de Instrucción al notificar la resolución pertenece al ámbito procesal y resulta ajena a la infracción del art. 1969 CG, siendo lo decisivo para la aplicación de dicho precepto que el Tribunal alcance la convicción de que el perjudicado pudo conocer que la vía penal, hasta entonces óbice para ventilar la acción civil, había concluido. En esta misma línea, la STS 19 de octubre de 2009, declara que la ausencia de notificación en forma no constituye óbice para que el plazo de prescripción discurra siempre que quede constancia en autos de que el interesado conoció por otras vías el contenido de la resolución judicial de archivo, a contar, desde luego, desde el día que se justifique que se tuvo el referido conocimiento.

Puede concluirse, entonces, a la luz de todo lo expuesto, que si no existió notificación, el plazo para ejercer la acción civil derivada del delito de terrorismo continúa abierto. Y es que, como consecuencia de lo anterior, en ningún momento pudo conocer el ofendido a partir de cuándo quedaba expedita la vía civil para reclamar una indemnización por responsabilidad civil derivada del delito terrorista. En el sentido apuntado puede invocarse el Dictamen del Consejo de Estado núm. 52.231, de 28 de julio de 1988, que resulta contundente al afirmar que, no constando notificación

nada obsta a que el proceso pueda concluir mediante otro tipo de resolución judicial configurada legalmente al efecto" (STC 120/1997, de 1 de julio). Lo que exige el TC, pues, es que se hayan respetado las garantías procesales y que la resolución judicial obtenida sea razonada y fundada en derecho, basándose en alguna de las causas previstas en la Ley (STG 46/1982, de 12 de julio). 
alguna, el efecto interruptivo se mantiene pues "la falta de conocimiento de la ordenación de la actuación penal no impide el mantenimiento de la interrupción de la prescripción ${ }^{46}$ ".

Resta por referirnos en esta sede a la vía excepcional contemplada por el Real Decreto 673/1992, de 19 de junio, por el que se regulan los resarcimientos por daños a víctimas de bandas armadas y elementos terroristas, aunque no se trata de la acción civil derivada de delito, que es la que nos ocupa y sobre cuya pervivencia tratamos. Dicha norma estableció que "La incoación de actuaciones judiciales por razón de los hechos delictivos a que se refiere el presente Real Decreto no impedirá la iniciación y tramitación del expediente administrativo" (art. 3.1. in fine). En efecto, a partir de este Real Decreto, la incoación y tramitación de un procedimiento penal no imposibilitó que se diera curso a la solicitud de indemnización en vía administrativa, frente a lo dispuesto, como es sabido, por el art. 114 de la LECr. En puridad el art. 114 LEGr no contempla propiamente una prejudicialidad penal ${ }^{47}$, sino que imposibilita, eso sí, el ejercicio de la acción civil nacida de delito o falta, pero no la que trae causa de la legislación tuitiva de protección a las víctimas del terrorismo, pues no tiene como soporte elementos subjetivos de dolo o culpa, sino una acción que se incardina en la amplia noción de asistencia y protección social, la cual no está necesariamente impedida por la pendencia de la causa penal.

46 Señala el Dictamen del Consejo de Estado núm. 52.231, de 28 de julio de 1988 que "No hay constancia en el expediente de cuándo el auto de sobreseimiento adquirió formalmente el carácter de firme, pues no consta notificación alguna. La cuestión, sin embargo, se sitúa en un plano de mayor generalidad, en inmediata relación con la previsión del artículo 109 de la LECr. y con las consecuencias que el perjudicado por el delito ha de soportar por el no ejercicio de la acción penal (o de la civil) en el proceso incoado. Conviene adelantar que el artículo 109 tiene un carácter meramente instrumental, informativo que no atribuye por sí, ni condiciona derecho alguno. Es el ejercicio de la acción el que determina el que, el ejerciente, asuma el conjunto de derechos y deberes, o de cargas, que resultan de la posición general departe". "Ciertamente, por regla general, no absoluta, son las partes personadas las destinatarias de los actos de notificación, instrumentos integrados en el derecho complejo a la tutela judicial efectiva. $Y$ si la parte procesal es debidamente instruida a través de las notificaciones oportunas, no podrán oponerse a la eficacia extintiva de la prescripción conductas en oposición al conocimiento que tiene de la causa." ... "No éste el si bien la señora P.C. fue instruida de la causa (la seguida ante el Juzgado de BaracaIdo, una vez que conoció dela misma el Juzgado Central), se desnaturalizaría el significado y alcance del artículo 109 (carácter meramente instruccional) si se anudara a la no constitución procesal como parte, la privación de su derecho, pues es lo que viene a significar la prescripción. También padecería si se exigiera una suerte de seguimiento - de imposible ejercicio legal y razonablemente-para obtener extraprocesalmente conocimiento de la conclusión de la causa. La causa penal puede ser en casos como el actual -no siempre necesariamente- un impedimento o un obstáculo a la pretensión indemnizatoria, no porque esta pretensión se ejercite en el proceso (obviamente, la acción indemnizatoria frente a la Administración con fundamento en la legislación resarcitoria citada no se hace valer en el proceso). Mientras el beneficiado por la indemnización especial no tenga conocimiento de la conclusión de la causa, el efecto interruptivo se mantiene. No puede mantenerse al mismo una "carga" (mostrarse parte): si acaso la carga podría predicarse de los órganos públicos, para que el designio dela legislación (protección económica de las víctimas del terrorismo) se cumpla. Considera pues el Consejo que la indemnización no debe denegarse". En otros términos, la falta de conocimiento de ordenación de la actuación penal no impide el mantenimiento de la interrupción de la prescripción.

47 El Consejo de Estado, llevado por un afán tuitivo, había afirmado con anterioridad al dictado de este Real Decreto 673/1992 que la tramitación de este tipo de expedientes no quedaba vedada por aplicación lo dispuesto en los arts. 111 y 114 de la LECr. 


\section{Pervivencia de acciones en el caso de que se pudiera probar la aplicación de la amnistía al responsable del atentado}

Cuando tiene lugar un extravío de expediente judicial por atentado terrorista se desconocerá cuál fue el curso del proceso penal incoado, por lo que hemos sostenido que debe ser posible imputar al Estado no sólo el daño moral derivado de la pérdida de oportunidad procesal o lucro cesante que genera la pérdida del expediente judicial, sino también el daño derivado de la imposibilidad de accionar la responsabilidad civil derivada del delito, en tanto aparezcan dichos autos y si es que aparecen. Nos planteamos ahora qué efectos sobre la acción civil que consideramos se derivarían de haberse aplicado alguna de las amnistías que contempló nuestro ordenamiento jurídico en la etapa preconstitucional.

Remontándonos al Real Decreto-Ley 16/1976, de 30 de julio sobre Amnistía, aplicable a los delitos y faltas cometidos con anterioridad al 30 de julio de 1976, en su art.2.1 estableció que "la amnistía otorgada dejará siempre a salvo la responsabilidad civil frente a los particulares". Esta amnistía, como es sabido, afectó, entre otros ilícitos penales, a los delitos y faltas de intencionalidad política y de opinión comprendidos en el CP o en leyes penales especiales, en tanto no hayan puesto en peligro o lesionado la vida o la integridad de las personas (art. 1).

Poco después, la Ley 46/1977, de 15 de octubre, de Amnistía dispuso que quedaban amnistiados: a) Todos los actos de intencionalidad política, cualquiera que fuese su resultado, tipificados como delitos y faltas realizados con anterioridad al día quince de diciembre de mil novecientos setenta y seis. b) Todos los actos de la misma naturaleza realizados entre el quince de diciembre de mil novecientos setenta y seis y el quince de junio de mil novecientos setenta y siete, cuando en la intencionalidad política se aprecie además un móvil de restablecimiento de las libertades públicas o de reivindicación de autonomías de los pueblos de España. c) Todos los actos de idéntica naturaleza e intencionalidad a los contemplados en el párrafo anterior realizados hasta el seis de octubre de mil novecientos setenta y siete, siempre que no hayan supuesto violencia grave contra la vida o la integridad de las personas (en su art. 1).

Sin perjuicio del sentido que pudiera tener aplicar la amnistía a actos terroristas, pues no se trata del lugar oportuno para el planteamiento de dicha discusión, debemos profundizar en la determinación de los efectos de la eventual amnistía, como decíamos, sobre la acción de responsabilidad civil derivada del delito ${ }^{48}$. La

48 Debe traerse a colación en este punto la STS (Sala de lo Contencioso-administrativo) de 28 de noviembre de 1986, que excluye del ámbito de aplicación de la Ley de amnistía de 1977 los móviles independentistas, diferenciándolos de los móviles autonomistas, considerando que el propósito de secesión o de independencia de Cataluña por la fuerza de las armas y mediante un ejército revolucionario no se encuentra en el ámbito de la citada Ley de Amnistía, a no ser mediante una interpretación extensiva que repugna a toda medida de gracia. Por su parte, la STS (Sala de lo Contensioso-administrativo) de 30 de diciembre de 
doctrina ha entendido que los efectos genéricos de la amnistía se extienden no sólo a la extinción de la pena, sino que también afectan a la acción penal, de modo que los procesos penales pendientes por delitos comprendidos en la Ley de Amnistía tendrán que ser sobreseídos ${ }^{49}$. Y, en relación a la responsabilidad civil, también la mayor parte de la doctrina ha considerado que la responsabilidad civil derivada de los delitos amnistiados no queda afectada por la amnistía ${ }^{50}$. La razón fundamental de esta pervivencia es que la responsabilidad civil no se extingue a menos que se declare expresamente en la misma norma reguladora de la amnistía. De este modo, habría que estar a lo dispuesto en cada Ley de Amnistía para comprobar si se contemplan o no estos efectos extintivos. Por lo que hace a la referida Ley 46/1977, esta estableció que "la amnistía determinará en general la extinción de la responsabilidad criminal derivada de las penas impuestas o que se pudieran imponer con carácter principal o accesorio" (art. 6, párrafo primero). En ningún momento aludió, pues, a la extinción de la responsabilidad civil derivada de los delitos amnistiados. Y tampoco puede entenderse que la responsabilidad civil pueda ser tenida como una pena accesoria ${ }^{51}$. También el TC convino en que "la amnistía extingue la punibilidady los efectos penales que el delito o infracción produce como hecho penal o sancionable, pero no los efectos que el delito o infracción produce como hecho simple" (STC 122/1984, de 14 de diciembre). Puede concluirse, en suma, que la eventual aplicación de la Ley de amnistía de 1977 no genera la extinción de la responsabilidad civil derivada de los actos amnistiados, ni para los causantes directos ni para el Estado español.

1980 señala que "cuando la Ley de Amnistía de 15 de octubre de 1977 habla del "móvil de restablecimiento de las libertades públicas", debe entenderse que tales libertades se refieren al respeto a los derechos humanos, a la participación del pueblo en tareas públicas, al pluralismo y pluripartidismo, a la libertad de asociación y de actuación política, a la libertad sindical y al establecimiento de un régimen democrático asentado en los tres poderes clásicos y presidido por unas Cortes representativas -uni o bicameralmente- cuyos Diputados o representantes sean elegidos por sufragio universal, directo y secreto".

49 ARROYO DE LAS HERAS, A.; MUÑOZ CUESTA, J.; Manual de Derecho Penal. Introducción-La ley penal-La pena, Aranzadi, 1989, p. 315.

50 ARROYO DE LAS HERAS, A.; MUÑOZ GUESTA, J. (1989: 315.) LINDE PANIAGUA, E., "Amnistía, control de constitucionalidad y responsabilidad patrimonial del Estado legislador", Revista Española de Derecho Administrativo, núm. 16 enero-marzo 1978, p. 107. ANTÓN ONEGA, J.; Derecho Penal; Ak al; $2^{a}$ Edición, 1986, p. 610. LOZANO CUTANDA, B., "El indulto y la amnistía ante la Constitución", en Estudios sobre la Constitución Española. Homenaje al profesor Eduardo García de Enterría, Civitas, Madrid, 1991. PÉREZ DEL VALLE, C., "Amnistía, Constitución y justicia material"; Revista Española de Derecho Constitucional, núm. 61, enero-abril, 2001. REGLERO CAMPOS, L. F., El plazo de prescripción de la acción de daños por hechos por los que se han seguido actuaciones penales; Aranzadi Civil, Vol. II, Parte Estudio, p. 2423, 1993 (ReferenciaWestlaw: BIB 1993\110)

51 ANTÓN ONECA, J. (1986: 610) y SAÍNZ MORENO, F. "Efectos materiales y procesales de la amnistía"; Revista de Administración Pública, núm. 87, septiembre-diciembre, p. 361 y ss. 
Responsabilidad del Estado Juez por extravío de expedientes judiciales sobre atentados terroristas-pérdida de oportunidad, prescripción y pervivencia de acciones civiles-

\section{Prescripción de los atentados terroristas y de la responsabilidad civil derivada del delito}

Aunque a día de hoy los delitos de terrorismo son imprescriptibles ex art. 131.4 $\mathrm{CP}$ si hubiesen causado la muerte de una persona, es posible que pudiera sostenerse la prescripción de los delitos que consideramos, al haber estado paralizado el proceso penal durante años y sin constar su finalización, ya fuera de forma provisional, mediante auto de sobreseimiento, o definitiva, mediante la aplicación de la correspondiente Ley de Amnistía. Debemos preguntarnos entonces qué suerte correría entonces la responsabilidad civil derivada del atentado terrorista.

Debe partirse de que la extinción de la acción penal no determina la extinción de la acción de responsabilidad civil derivada del mismo. El Consejo de Estado se ha referido a esta cuestión en su Dictamen 692/2001, de 19 de abril, señalando que "la extinción de la acción penal no determina en modo alguno lo propio en la acción de responsabilidad civil. Distinto sería que, como consecuencia del tiempo transcurrido, la acción civil fuera declarada ella también prescrita o, ya en el terreno de los hechos, resultara completamente ineficaz".

Debe entenderse, en consecuencia, que el cómputo del plazo de prescripción de la acción quedó interrumpido desde que se iniciaron las actuaciones judiciales cuyo expediente se encuentra extraviado, por lo que en la medida en que no ha existido notificación de la resolución finalizadora del proceso penal en ninguno de los posibles sentidos comentados, en ningún caso puede entenderse que la acción civil ha expirado, sino que, muy al contrario, se encontraría expedita a día de hoy, hasta que, de aparecer el expediente, y ser esta circunstancia notificada al perjudicado, pudiera iniciarse el correspondiente proceso para su ejercicio, en cuyo caso podría conocerse el estado en que se encontraban las actuaciones cuando desapareció el expediente, esto es, si se suspendió su tramitación antes de ser objeto de finalización siquiera provisional, si fue objeto de sobreseimiento provisional, si finalizó mediante sentencia condenatoria y/o si, además, fue objeto o no de aplicación de las medidas de gracia contempladas en la Ley deAmnistía, cualquiera que fuera el estado de tramitación del proceso penal. En este sentido, y como se ha señalado supra, el Real Decreto 673/1992, estableció que "La acción para reclamar prescribe por el transcurso del plazo de un año computado a partir de la fecha del hecho que lo originó ... el plazo de prescripción quedará interrumpido desde que se inicien las actuaciones judiciales por razón de los hechos delictivos a que se refiere el presente Real Decreto, volviendo a correr desde que se terminen (art. 8) ${ }^{52}$.

Como fundamento de nuestra postura, el Consejo de Estado, en su reciente Dictamen 481/2016, de 20 de octubre de 2016, emitido en relación las solicitudes de

52 Tampoco los Acuerdos del Consejo de Ministros de 16 de marzo de 1979 y 25 de marzo de 1983 establecieron plazo alguno al respecto. 
indemnización formuladas por los familiares de los militares españoles fallecidos en el accidente aéreo ocurrido el día 26 de mayo de 2003 en Trabzon (Turquía) cuando regresaban a territorio nacional procedentes de Afganistán, donde habían participado en una misión internacional, ha entendido que, a pesar de haberse presentado una de las reclamaciones fuera del plazo del año, y a pesar de la dicción del art. 142.5 de la hoy derogada LRJPAC, "no cabe apreciar un ejercicio extemporáneo de la acción resarcitoria, considerando que, con posterioridad al siniestro, se tramitó un expediente de fallecimiento en el que se declaró como acaecida en acto de servicio la muerte del mencionado militar y, sobre todo, fueron tramitados diversos procedimientos en sede judicial que han resultado determinantes para el esclarecimiento de los hechos y a los que debe atribuirse, por ende, virtualidad interruptiva de la prescripción". 

terroristas-pérdida de oportunidad, prescripción y pervivencia de acciones civiles-

\section{BIBLIOGRAFÍA}

ANTÓN ONECA, J., Derecho Penal; Ak al; 2a Edición,1986.

ARCOS VIEIRA, M.L., "La 'pérdida de oportunidad' como daño indemnizable" en Estudos de direito do consumidor, Faculdade de Direito da Universidade de Coimbra, núm. 7, 2005.

Responsabilidad civil: nexo causal e imputación objetiva en la jurisprudencia, Thomson Aranzadi, Cizur Menor, 2005.

ARROYO DE LAS HERAS, A.; MUÑOZ CUESTA, J., Manual de Derecho Penal. Introducción-La ley penal-La pena, Aranzadi, 1989.

ASENSI PALLARÉS, E., "La evolución de la doctrina de la pérdida de oportunidad en responsabilidad médica”, Revista Cesco de derecho de consumo, núm. 8/2013.

ASÚA GONZÁLEZ, G.I., "Responsabilidad civil médica” en REGLERO CAMPOS, L.F. Y BUSTO LAGO, J.M (Coord.), Tratado de responsabilidad civil, Vol.

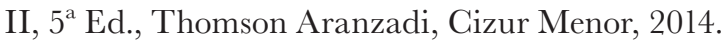

BONET FRIGOLA, J., Responsabilidad civil del juez y del Estado por la actuación del poder judicial, Revista española de derecho administrativo, $\mathrm{N}^{\circ}$ 67, 1990.

CACHÓN CADENAS, M., "Efectos del sobreseimiento", Revista de Derecho procesal, Ed., Bosch, núm., 3-4, Barcelona, 2008.

CRESPO MORA, M.C., La responsabilidad del abogado en el Derecho Civil, Thomson Civitas, Gizur Menor, 2005.

DE ÁNGEL YÁGÜEZ, R., "La responsabilidad civil del abogado" en Indret, núm. 1, 2008.

DELGADO DEL RINCÓN, L. E., "Algunas consideraciones sobre el régimen jurídico-constitucional de la responsabilidad judicial”, Revista del poder judicial, núm. 61, 2001.

Poder judicial y responsabilidad. La responsabilidad del Estado juez, Centro de Estudios Políticos y Constitucionales, Madrid, 2002.

DÍEZ PICAZO, L., Ensayos Jurídicos. Tomo II. Navarra, Cizur Menor, Aranzadi, 2011.

EMILJALIL, J., Responsabilidad del Estado en la esfera jurisdiccional ante la pérdida de instrumentos consignados en un expediente judicial, Revista de responsabilidad civily seguros: publicación mensual de doctrina, jurisprudencia y legislación, núm. 9, 2013. 
ESCUSOL BARRA, E., Estudio sobre la Ley orgánica del poder judicial: la responsabilidad en la función judicial, jueces, tribunales y estado : posición del Ministerio Fiscal, Editorial Constitución y Leyes, COLEX, 1989.

FERNÁNDEZ DE CASADEVANTE, G., "El derecho al acceso a la Justicia y a una respuesta efectiva en el marco del sistema regional europeo de protección de los Derechos Humanos" , Eguzkilore: Cuaderno del Instituto Vasco de Criminología, núm. 27, 2013.

GUILLÓ SÁNCHEZ-GALIANO, A., "Aspectos problemáticos de la pérdida de oportunidad", Revista española de la función consultiva, núm. 16, 2011.

LASARTE, C., Principios de Derecho Civil II, Derecho de Obligaciones, Marcial Pons, 2007.

LINDE PANIAGUA, E., "Amnistía, control de constitucionalidad y responsabilidad patrimonial del Estado legislador", Revista Española de Derecho Administrativo, núm. 16, enero-marzo 1978.

LLAMAS POMBO, E., "Las dudas sobre el daño por pérdida de oportunidad" en Practica de Derecho de Daños, núm. 110, 2012.

LOZANO GUTANDA, B., "El indulto y la amnistía ante la Constitución", en Estudios sobre la Constitución Española. Homenaje al profesor Eduardo García de Enterría, Civitas, Madrid, 1991.

MANTEGA VALDELANDE, V., "Reclamación de responsabilidad a las Administraciones Públicas (VIII) (Responsabilidad derivada de actuaciones judiciales)", Actualidad Administrativa, núm. 6, Sección Práctica Profesional, Quincena del 16 al 31 Marzo, tomo 1, Editorial LA LEY, 2011.

MARTÍN DEL PESO, R., "El daño moral: determinación y cuantía. Algunos aspectos de su problemática jurisprudencial", en HERRADOR GUARDIA, M. J. (director), Derecho de daños, Thomson Reuters-Aranzadi, Cizur Menor, 2013.

MARTÍNEZ RODRÍGUEZ, N., "La doctrina de la pérdida de oportunidad en la responsabilidad sanitaria", en LLAMAS POMBO, E. (dir.), Estudios sobre la responsabilidad sanitaria: un análisis interdisciplinar, 2014.

MARTÍN-RETORTILLO BAQUER, L., "De la eficiencia y economía en el sistema de responsabilidad patrimonial de la Administración: de las indemnizaciones derivadas de hechos terroristas", Revista Vasca de Administración Pública. Herri-Arduralaritzako Euskal Aldizkaria, núm. 19, 1987.

MEDINA ALCOZ, L., La teoría de la pérdida de oportunidad. Estudio doctrinal y jurisprudencial de derecho de daños público y privado, Thomson Civitas, Cizur Menor, 2007. 
Responsabilidad del Estado Juez por extravío de expedientes judiciales sobre atentados terroristas-pérdida de oportunidad, prescripción y pervivencia de acciones civiles-

MENÉNDEZ MENÉNDEZ, A., "La responsabilidad patrimonial del Estado por el funcionamiento de la Administración de justicia en la Ley Orgánica del Poder Judicial", Gobierno y administración en la Constitución, Dirección General del Servicio Jurídico del Estado.

MONTERO AROCA, J., Responsabilidad civil del juez y del estado por la actuación del poder judicial, Tecnos, 1988.

PARRA LUCÁN, M. A. Y REGLERO CAMPOS, L.F., "La responsabilidad civil de los profesionales del derecho" en Tratado de Responsabilidad Civil, Vol. II, $5^{\text {a }}$ Ed., Thomson Aranzadi, Cizur Menor, 2014.

PÉREZ DEL VALLE, C., "Amnistía, Constitución y justicia material”; Revista Española de Derecho Constitucional, núm. 61, enero-abril, 2001.

REGLERO CAMPOS, L. F., "El plazo de prescripción de la acción de daños por hechos por los que se han seguido actuaciones penales" Aranzadi Civil, Vol. II, Parte Estudio, 1993 (ReferenciaWestlaw: BIB 1993\110).

REGLERO CAMPOS, L.F. Y MEDINA ALCOZ, L., "El nexo causal. La pérdida de oportunidad. Las causas de exoneración de responsabilidad: culpa de la víctima y fuerza mayor", en REGLERO CAMPOS, L.F. (Coord), Tratado de responsabilidad civil, Vol. I, $5^{\text {a }}$ Ed., Thomson Aranzadi, Cizur Menor, 2014.

SAÍNZ MORENO, F., "Efectos materiales y procesales de la Amnistía"; Revista de Administración Pública, núm. 87, septiembre-diciembre.

SÁNCHEZ CARO, J., "La teoría de la pérdida de oportunidad, Revista española de la función consultiva", núm. 16, 2011.

SANZ ACOSTA, L., "La responsabilidad civil judicial", Estudios de derecho judicial (Ejemplar dedicado a: La responsabilidad personal del juez), núm. 153, 2008.

SEGRELLES DE ARENAZA, I., "Sobreseimiento provisional, reapertura del proceso y derechos fundamentales", Cuadernos de Política Criminal, núm. 54, Madrid, 1994.

SERRA RODRÍGUEZ, A., La responsabilidad civil del abogado, Aranzadi Editorial, $2^{\mathrm{a}}$ ed., Elcano, 2001.

TORNOS MÁS, J., "La responsabilidad patrimonial del estado por el funcionamiento de la administración de justicia. Algunos aspectos conflictivos, con especial referencia al procedimiento para hacerla efectiva", Revista Española de Derecho Constitucional, núm. 13, 1985.

XIOL RÍOS, J. A., El daño moral y la pérdida de oportunidad, Revista jurídica de Catalunya, Vol. 109, No 1, 2010. 